Institutul de Filologie Română „Alexandru Philippide”, Iași

\title{
SPAȚIUL DACOROMÂNESC DE LA EST DE CARPAȚI: REPERE DIN MEMORIA LIMBII² [1]
}

0.1. Chiar prin titlu, vrem să facem cunoscută o realitate puțin obișnuită: în cazul limbii române, cercetări din domeniul dialectologiei, disciplina varietății diatopice, așadar reprezentând preocupările pentru analiza deosebirilor lingvistice teritoriale funcționale în ceea ce privește o limbă, sunt cele care ilustrează, involuntar și în parte indirect, dar esențial, unitatea etnolingvistică a vorbitorilor dacoromânei. Un asemenea fapt a fost posibil, în general, atunci când, după investigații particulare, privind realitățile lingvistice caracteristice unor subunități spațiale restrânse, geografia lingvistică, sub forma cartografiei lingvistice preocupată de nivelul 1 i m b i 1 o r, a înfățișat ansambluri, cu rezultate diferite în funcție de situația acestora. Fără a intra în amănunte și fără a ignora proiecțiile, ne putem referi la concluzii care au fost și sunt desprinse după apariția, respectiv publicarea, peste timp, a unor lucrări „clasice" de gen, de tipul Deutscher Sprachatlas (Wenker, Wrede, Mitzka ș.a.; începutul tipăririi - 1881) sau Atlas linguistique de la France (Gilliéron-Edmont, 1902-1910).

0.2. Întrucât obiectivul principal al acestui studiu este locul graiurilor moldovenești din perspectiva dacoromânei, trebuie să insistăm asupra faptului că, la încheierea primului război mondial, în lumea politicii, statutul dacoromânei a fost unul dintre factorii luați în considerație din perspectivă geopolitică: obținerea unui anumit statut pentru teritoriul locuit de vorbitorii idiomului respectiv, cu efecte asupra proiecției și organizării statale. Evident, nu este vorba de statutul limbii române $\hat{\imath}$ lumea științei, ci de percepția lui dincolo de limitele acesteia, dar una, venind dinspre cultura generală a epocii, hotărâtoare pentru sfera politicii și a diplomaţiei. De fapt, în discuție este continuarea ideilor secolului al XIX-lea, al „naţionalităților”, privitoare la eliberarea şi independența națională a popoarelor ce se aflaseră sub dominația unor state de altă naționalitate, limbă şi (uneori) religie, tendință legitimată și prin

\footnotetext{
2 Lucrarea a fost susținută în plenul conferinței Lexic comun / Lexic specializat. Limba și cultura română în context național și european: evaluări și perspective la Centenarul Unirii, Galați, 26-27 octombrie 2018.
} 
întrebuințarea unei limbi comune, profesându-se cunoscutul principiu al autodeterminării naționale. Ca drept ., al popoarelor" ce a figurat printre cele 14 puncte ale programului propus de preşedintele american Woodrow Wilson la Conferința de Pace de la Paris (1919-1920), în urma lucrărilor căreia România şi-a înfăptuit unitatea națională, prin unirea Transilvaniei, Banatului, Bucovinei şi Basarabiei cu Vechiul Regat.

0.3. Din această perspectivă, pentru mediul la care ne-am referit, cu un punct de plecare dinspre cultura generală a epocii, trebuie să considerăm chiar absența, cândva, a recunoașterii limbii române drept idiom romanic în sine, în primul rând date fiind dificultățile de identificare a statutului respectiv, atât din cauza izolării față de ansamblul centraleuropean și occidental al Romaniei, cât și (o curiozitate!) din cauza scrierii acesteia cu alfabet slavon, iar, în al doilea rând, mai târziu, şi din cauza plasării ei prin proiecții aparte, de exemplu ca limbă aparținând unei așanumite „uniuni lingvistice balcanice”, ca să ne referim numai la fapte cu caracter de obiectivitate.

0.4. În afară de acestea, la 100 de ani de la Marea Unire, nu ne este permisă neglijarea subiectivităților, în discuție fiind mai ales statutul așazisei „limbi moldovenești”, ceea ce interesează și din perspectiva dacoromânei ca reflectare a caracteristicilor romanităţii orientale. Identificarea, din perspectiva teoriei domeniului, a presupusei „limbi" la care ne-am referit ar conduce nu doar spre ideea unei diferențieri lingvistice în stare să modifice parțial datele generale ale problemei în discuție, ci însăși îndrituirea imaginii lingvistice presupuse de granițele statului național român. Dar, prin cercetarea obiectivă a realității, clarificarea problemei putea susține ideea respectivă.

0.5. Cu limitele impuse de o intervenție cum este cea de față, în continuare încercăm răspunsuri la aceste probleme.

1. Necunoașterea în Occident, normală, a statutului limbii române ca limbă romanică a fost înfățișată mai ales de Eugeniu Coșeriu, ocupându-se de luminile pe care avea să le aducă preocuparea pentru compararea textului „Rugăciunii domnești” în diferite limbi. Stăruia impresia, și din cauza alfabetului cu care era scrisă limba română, la care ne-am referit, că aceasta este un idiom slav; filologii care au urmărit textul rugăciunii Tatăl nostru în diferite limbi s-au convins că, în cazul limbii române, se află în prezența unei limbi romanice. Așadar, conform situației înfăţișate în studii și antologii apărute între 1580 (G. Genebrardus) și 1787 (L. Hervás y Panduro), acest text a fost revelator pentru latinitatea românei (Coșeriu 
1994a: passim; varianta "Tatălui nostru” transcrisă de suedezul G. Stiernhielm, publicată în 1671, provenea de la N. Milescu).

Excurs 1. O confuzie înrudită cu aceea evocată anterior a stăruit până foarte târziu în Europa, la un nivel neașteptat; o dovedește faptul că, până prin anii '60 ai secolului trecut, la facultăți de litere din Franța sau din Germania, dacă nu figura ca obiect de studiu direct la „limbi slave”, româna era inclusă în programele departamentelor de „limbi orientale"!

2. Evident, pentru discuția de față nu interesează punctele de vedere privind situația graiurilor vorbite pe teritoriile de la est de Prut și a moldovenilor din acest areal ca dacoromâni, după izvoare interne (paratexte la cărțile de cult, cronici, descrieri de călătorie etc.), ci opinii și opțiuni ale cercetătorilor lingviști, pentru care trimitem la autori și opere capitale din Occident de până la anii 1918-1920 și, dată fiind situația prezentată în Excursul 1, și în anii următori, cu agravarea tratării problemei prin exacerbarea afirmării existenței unei "limbii moldovenești". Prezentării titlurilor le adăugăm scurte informații de referință:

2.1. În 1911, pe baza unei bogate bibliografii de profil, Wilhelm Meyer-Lübke publică un dicționar etimologic al limbilor romanice, care ne atrage atenția și pentru faptul că, în cadrul fiecărei „intrări”, cuvintele din limba română provenind din latină ocupă prima poziție.

Exemple: « 487. annus "Jahr" rum. an, vegl. yan, ital. anno, log. annu, engad., friaul., frz., prov. an, katal. any... » etc.; " 1668 . caput "Kopf", "Haupt”, „Ende” rum. cap, vegl. kup, ital. capo, lomb. ko, log. kabu, kabidu...» etc.; " $\underline{3382}$. flos "Blume" rum. floare, it. fiore, log. flore, engad., friaul. flur, frz. fleur, prov., cat. flor...» etc.; « 5730. mŭlier „Weib”, 2. mŭliére...2. Rum. muiere, ital. moglie, aital. mogliera, log. mudzere, engad. mul'er, friaul. muyer, afrz. moillier, prov. molher, katal. muller, span. muher, portg. molher» etc. (Meyer-Lübke 1911: passim).

Nicio referire la vreun dialect al dacoromânei! Există însă referiri la dialectele din sudul Dunării, iar, în ceea ce privește Romania occidentală, trecând peste trimiterea la idiomuri cum sunt provensala ori catalana, sunt citate forme din dialecte de rangul (dacă ne referim doar la lista precedentă) vegliot, logudorez, engadinez, friulan etc.

2.2. În 1925, Matteo Bartoli, prezentând principiile, obiectivele și metodele „neolingvisticii”, evaluează Dacia și Iberia ca „arii laterale” ale Romaniei; printre exemplele ce ilustrează această teorie: frumos - hermoso; (a) fierbe - hervir; masă - mensa; mai - más; atunci - entonces; zi - dia (Bartoli 1925: passim). Reținem faptul că este descoperit un anumit specific al limbii române, dar în cadrul Romaniei și, mai mult, prin asemănarea cu o altă limbă romanică, spaniola. 
2.3. În 1949, după importante și numeroase contribuții în acest domeniu, Carlo Tagliavini publică o monografie consacrată originilor limbilor neolatine (Tagliavini 1949), la care trimitem după o traducere în limba română a celei de a șasea ediții, din 1972, a textului (Tagliavini 1977).

2.3.1. Așadar, în monografia citată a lui Tagliavini, în capitolul al VIlea, intitulat Limbile și dialectele neolatine, după $§ 63$ (Clasificarea limbilor neolatine), paragraful 64 este consacrat limbii române. Iată, mai întâi, locul acesteia, după cele mai importante clasificări. Pe când „Friederich Diez [1836-1843]... distingea numai șase limbi neolatine: italiana și valaha (= româna), care formau secțiunea orientală, portugheza și spaniola, care formau secțiunea occidentală și provensala și franceza, care formau secțiunea nord-occidentală" (Tagliavini 1977: 280), așadar grupate numai în trei „secțiuni”, Tagliavini enumeră douăsprezece limbi, plasate în patru grupe, după criterii predominant geografice, în ordinea: româna este "balcano-romanică”, dalmata, italiana, sarda și ladina (sau retoromana) sunt „italo-romanice”, franceza, franco-provensala, provensala (plus gascona) și catalana sunt "galo-romanice", spaniola şi portugheza sunt "ibero-romanice" (Tagliavini 1977: 283).

Excurs 2. Pentru Tagliavini denumirea de „balcano-romanică” poate fi aplicată în totalitate românei "numai dacă se admite și ipoteza reimigrării" (op.cit., p. 285; cf. 299); pentru semnificația termenului, cf., infra, § 6.2.2.

2.3.2. Cât despre română, „singura limbă romanică păstrată în răsăritul Europei", se consemnează că "se împarte în patru dialecte principale", prezentându-se, destul de sumar, "macedoromâna sau aromâna", "meglenoromâna sau meglenita" și „istroromâna" (p. 288-290), după ce, pe primul loc, este tratată "dacoromâna", "vorbită pe teritoriul României de astăzi, în Basarabia și într-o parte din Bucovina, aparținând în timpul și după cel de al doilea război mondial la URSS, ca și într-o parte din Banatul care aparține Iugoslaviei, în câteva sate din Bulgaria și din Ungaria, lângă granița românească" (p. 285-286). Acestor precise informații privind acoperirea teritorială, le urmează o prezentare, pe provincii, vizând (sub)structura dialectală: „Ea [dacoromâna] se împarte în mai multe varietăți dialectale, nu prea diferențiate între ele, pe malul stâng al Dunării (Moldova, Valahia, Transilvania, Banat, Bucovina, Basarabia) și doar în mică parte pe malul drept (Dobrogea și o parte a Banatului iugoslav)" (Tagliavini 1977: 285-287).

Excurs 3. Poate că Tagliavini a fost influențat de Gustav Weigand în ceea ce privește nominalizarea situației lingvistice a Bucovinei și Basarabiei (cf. Weigand 1904). Pe de altă parte, formula de mai sus, ,[varietăți] nu prea 
diferențiate între ele", ne-a reamintit o caracterizare similară, probabil prin comparație cu situația dialectală a Italiei, a unui alt expert în domeniu, Karl Jaberg. Acesta, referindu-se la diferențele dialectale, minime, de pe teritoriul dacoromânei, după ce participase, în 1929, la o anchetă de teren dintr-o localitate din vecinătatea Clujului a membrilor Muzeului Limbii Române, scria: "Je näher die Mundart der Sprache des Fragers - und hier sind die mundartliche Merkmale, nicht sehr ausgesprochen -, desto schwieriger ist für den Auskunftgeber, mundartliche und schriftsprachliche (oder städtische) Formen auseinanderzuhalten" (Tagebuchbläter, citat în Dumistrăcel 1978: 32; evidențierea grafică din citat ne aparține). Este un punct de vedere asupra căruia Jaberg va reveni.

2.3.3. În legătură cu „omogenitatea” dialectală a limbii române în comparație cu limbile romanității centrale, trăsătură pusă în lumină chiar de apariția Atlasului lingvistic român, mai notăm observații ale aceluiași Karl Jaberg, autor, împreună cu Jakob Jud, al monumentalului Sprach- und Sachatlas Italiens und der Südschweiz (8 volume, Zofingen, 1928-1940): „Die Eigenart des rumänischen Sprachgebietes und damit des ALR wird bedingt durch die soziale Einheitlichkeit der durchaus dominierenden landwirtschaftlichen Bevölkerung, durch den relativ kleinen Unterschied zwischen der Reichssprache und den Dialekten, durch die - an der Zentralromania gemessen - merkwürdige Gleichartigkeit der Mundarten" (Jaberg 1940: 51; traducere, după Cazacu-Todoran 1956, p. 188: „Particularitatea domeniului lingvistic dacoromân și implicit a ALR este condiționată de unitatea socială a populației dominant agricole, de relativ puțin pronunțata deosebire dintre limba națională și dialecte, de surprinzătoarea - în comparație cu Romania centrală - omogenitate a dialectelor").

2.3.4. În ceea ce privește situația lingvistică a Basarabiei, la Tagliavini găsim o tratare extinsă a problemei, pornind de la statutul acestei provincii, înainte și, apoi, după anexarea, în 1812, a Moldovei de la est de Prut, ca și după re-anexarea ei după cel de al doilea război mondial, cu privire la politicile lingvistice ale imperiului țarist și ale U.R.S.S., inclusiv cu privire la "fundamentarea" lingvistică a aşa-numitei "limbi moldovenești" (Tagliavini 1977: 286-289). Asupra unor probleme discutate de Tagliavini vom reveni (cf. § 4.3).

3. Reevaluări terminologice (derutante) privind statutul dacoromânei

3.1. „Carpatistica”. Statutul dacoromânei ca reprezentantă a latinității orientale, inclusiv statutul (real) al graiurilor moldovenești dintre Prut şi Nistru, sunt, de fapt, anulate în cazul unei clasificări a dacoromânei, dar și a „limbii moldovenești” printre idiomurile de coloratură dialectală 
"carpatică". Rețeaua de puncte a operei intitulată Общекарпатскиũ Диалектический Атлас ("Atlasul dialectologic carpatic comun" /OKDA/, 7 volume apărute între anii 1998 - 2003), proiect înscris în domeniul de studii numit „carpatistică” (S.B. Bernștein) cuprinde localități din țările europene Polonia, fosta Cehoslovacie, Ungaria, Ucraina, Republica Moldova, fosta Iugoslavie, pentru care s-au făcut anchete ad-hoc. România este reprezentată pe bază de informații preluate din hărțile unor atlase publicate anterior la noi iar, semnificativ, Bulgaria este absentă (spații albe pe hărți), în pofida interesului, declarat, al inițiatorilor și autorilor întreprinderii, pentru „spațiul lingvistic carpato-balcanic". De altfel, proiectul OKDA, inițiat de Comitetul Internațional al Slaviștilor și realizat sub conducerea acestui for, avea ca obiectiv (într-o formulare cel puțin ambiguă) „clarificarea rezultatelor esențiale ale procesului contactelor de durată dintre dialectele heterogene din spațiul carpatic, ce au avut ca efect numeroase similitudini în domeniul lexico-semantic în primul rând" (traducere după varianta în limba franceză a Cuvântului înainte la volumul introductiv, semnat de S.B. Bernștein, președintele Comitetului menționat; cf. 1987_OKDA_vstup.pdf.).

Excurs 4. În ceea ce ne privește, Academia Română a declinat participarea la alcătuirea OKDA, suspectând reprezentarea limbii române ca limbă „carpatică" cu preocupare vădită pentru supralicitarea prezenței elementelor slave din lexicul dacoromânesc, intuită ca sursă pentru deformări din punctul de vedere științific. Contacte cu institutele academice de profil din România au fost întreprinse, în 1973, de cercetătoarea sovietică Galina Klepikova (de la Institutul de Slavistică şi Balcanistică al Academiei de Științe a U.R.S.S.), căreia nu i-a fost refuzată însă efectuarea de anchete proprii în România, ce au rămas la nivelul sondajelor.

3.2. Este posibil ca, astfel, să se fi procedat preventiv, spre a se evita o confuzie, cel puțin terminologică, printr-o separare sui-generis a dacoromânei de celelalte limbi romanice, ce se produsese, cumva, anterior, și prin plasarea acesteia în clasa „limbi balcanice” (concept cunoscut și sub numele de „Balkansprachbund"), cu puncte de vedere puse în discuție încă de B. Kopitar (1829), preluate și dezvoltate de Gustav Weigand $(1925,1928)$ și puse într-o nouă lumină de Kristian Sandfeld, care se ocupă de "lingvistica balcanică" (1930). Este o asociere, originală, dar temerară (și după aprecierile altora), a unor limbi neînrudite (româna, greaca, albaneza, bulgara), dar prezentând anumite trăsături comune, asupra căreia nu stăruim și datorită faptului că nu se referă, esențial, la structuri dialectale ale dacoromânei. Printre cei care au studiat și, prin aprofundarea analizei unor fapte, au limitat importanța conceptului a fost și Eugen Coșeriu, 
acuzând, în diverse cazuri, clasificarea drept "balcanisme” a unor "romanisme", fenomene lexicale și semantice explicabile prin latina orientală, unele ducând la vechea greacă (Coșeriu 1982: passim; cf. Dumistrăcel-Hreapcă 2018: § 3.1.2).

4. Negarea unităţii lingvistice a dacoromânei, având eventuale reflexe, chiar indirecte, în ceea ce privește însuși profilul statal al României, a fost agresiv formulată în legătură cu atribuirea unui nivel de „limbă (literară)" graiurilor românești de la est de Prut și de Nistru, mai ales în diverse etape ale politicii (și poliției) lingvistice de după instituirea unui stat (federativ) moldovean din componența U.R.S.S. Ne vom referi doar la câteva aspecte, concludente, ale punerii în aplicare a politicii respective, în completarea celor trecute deja în revistă în Tagliavini 1977 (cf., supra, § 2.3.3).

4.1. Diversiunea separării unei părți din subdialectul moldovenesc ca „limbă” propriu-zisă a început, de fapt, sub imperiul țarist, în perioada 1905-1917. Lucrurile au căpătat o cu totul altă turnură în 1924, după crearea R.A.S.S. Moldovenești, având ca limbă oficială "limba moldovenească”, forjată după norme, în special cele fonetice, stabilite pe baza graiurilor vorbite în Transnistria, iar, din punctul de vedere al lexicului, cu multe elemente ruseşti şi ucrainene. Un teoretician local, Leonid Madan, afirma, în 1926, că:

„Limba moldoveneascî, în care grăieşti amu norodu moldovenesc, este limbî sînistătătoari, diosăghitî di limba romîneascî, şî sî diosăgheşti şî de limba tuturor cărțîlor moldoveneşti tipăriti păn la organizarea RASSM" (Bahnaru 2016: 14).

În terminologia „științifică” a acestei limbi se foloseau de preferință calcurile, după model rusesc; de exemplu, într-un manual de zoologie de la Tiraspol, "cefalopodele" erau cunoscute sub numele de capochişioarnişi, iar "gasteropodele" pînticochişioarnişi. Vasile Bahnaru (2016: 14, 16) citează exemple cum sunt următoarele: ",aeroplanul” era sîngurzburător, "barometrul” aeromăsurător, "declinarea” aplecare, "pluralul” multuratec etc.

Trecem peste nuanțări din etapele ce au urmat după 1944, pentru a aminti doar luări de poziție intervenite după 1989 - adoptarea alfabetului latin, 1991 - româna proclamată „limbă oficială”, dar, după 1994, revenirea la denumirea „limbă moldovenească”, cu eschive semioficiale și editoriale de tipul „limba maternă” sau "materna” (de exemplu, s-au publicat manuale și culegeri de exerciții cu titlul „Materna în școală”).

4.2. În pofida caracterului extrem de selectiv al acestei prezentări, trebuie să amintim un moment semnificativ al imixtiunii (brutale) a 
politicului în practica lingvistică. În anul 2003 apare un Dicționar moldovenesc-românesc, al lui Vasile Stati. Câteva cuvinte şi definiții din această parodie lexicografică ne scutesc de comentarii (în lista ce urmează pe prima poziție se află cuvântul pretins moldovenesc, iar pe a doua corespondentul românesc):

"catrință - şorț de lînă ce poartă țărancele ca fustă deasupra cămăşii; fotă dublă; erbiu - verde-saturat; etac - iatac; franzelă - bulcă; gîscoi - gînsac; încă - mai ales; lighean - albie de tablă pentru spălat rufele; priseagă - prisacă; turmă - mulțime (de furnici); zarnacadea - narcisă".

Excurs 5. Am fi renunțat la evocarea acestei vădite aberații, a unui neprofesionist, însă, recent, la al 51-lea Simposion al Atlasului Limbilor Europei (Baia Mare, 27 iunie - 1 iulie 2018), pe marginea comunicării noastre (în colaborare cu Luminița Botoșineanu), Dialectologie et géographie linguistique concernant le parlers roumains en Moldavie et Bucovine / Dialectology and Geolinguistics of Romanian Sub-dialect spoken in Moldova and Bucovina, trecând în revistă fapte de natura celor analizate și în textul de față, o lingvistă din delegația rusă, Natasha Donadze, a susținut că, deși situația graiurilor populare constituie un aspect aparte, totuși, în Republica Moldova, ar exista o limbă moldovenească oficială „funcțională”, deosebită de limba română literară. Cum stau lucrurile și în această privință, ne-o dovedește chiar încercarea lui Vasile Stati de a-și argumenta punctele de vedere folosind limba "moldovenească” (firește!) în prefața dicționarului său, intitulată „Expunere de motive” (cităm după ediția din 2003, cu precizarea că nu ne propunem critica afirmațiilor):

„Limba moldovenească dispune de aceleași caracteristici pe care le au multe idiomuri vorbite de diferite popoare: originea, structura gramaticală, fondul lexical de bază comun; iar în temeiul acestor realități - înrudire pînă la gradul de «reciproc inteligibile». Deosebirea esențială, principală și definitorie a idiomurilor din atare contexte, inclusiv a limbii moldovenești din ramura lingvistică romanică de răsărit, este că ele au lingvonime (glotonime) diferite. Astfel, tipul oriental de vorbire romanică a dat naștere la denumirile de limbă (lingvonime): moldovenească, vlahă, valahă (românească), dalmată (dispărută)" (p. 3). Sau: „În pofida legislației internaționale privind drepturile popoarelor, relațiile între state, în pofida bunului simț, judecînd nu numai după declarații, ci și după fapte, antimoldovenismul a devenit, pare-se, doctrină ideologicoștiințifică oficială a statului românesc" (p. 9).

Astfel de mostre dintr-un registru al limbii oficiale moldovenești, "funcționale", ne scutesc, de asemenea, de orice comentarii.

4.3. Referindu-se la practicile de „purificare lingvistică” la care recurgeau autoritățile de la Chişinău (susținute și astăzi în împrejurări de tipul celor prezentate supra, § 4.2), susținând ideea existenței unei "limbi moldovenești", Eugeniu Coșeriu, în cadrul conferinței ştiințifice Unitatea limbii române - cu privire specială la Basarabia şi Bucovina: 
https://ro.wikipedia.org/wiki/Eugen_Co\%C8\%99eriu - cite_note-4, a reiterat opinia, pe care a sust,inut-o mereu, că

"A promova sub orice formă o limbă moldovenească, deosebită de limba română este, din punct de vedere strict lingvistic, ori o greşeală naivă, ori o fraudă ştiințifică. Din punct de vedere istoric şi practic este o absurditate, o utopie şi, din punct de vedere politic, e o anulare a identității etnice şi culturale a unui popor şi deci un act de genocid etnico-cultural" (Coșeriu 1994b; cf. și Coșeriu 2002).

Pentru lumea științifică occidentală, dincolo de limitarea cronologică (de actualitate) și de politică (sau, de fapt, de poliție) lingvistică locală, poziția romanică a dacoromânei a fost, cu autoritatea competenței, la nivelul responsabilității epistemice, abordată de un Alf Lombard, ocupându-se de „normarea” limbii române (Lombard 1956/1959), de Carlo Tagliavini, anterior Originilor, reacționând chiar față de teza existenței unei limbi literare moldovenești (Tagliavini 1956/1959) sau, cel mai cuprinzător, de Klaus Heitmann, referindu-se și la literatura moldovenească (Heitmann 1956).

4.4. Poziția dialectologilor de la Institutul de Lingvistică al Academiei de Ştiințe a Republicii Moldova

4.4.1. Luăm în considerație, preponderent, puncte de vedere venind de la specialiști dialectologi, chiar din perspectiva geografiei lingvistice. Astfel, s-a continuat publicarea materialelor prelevate pe teren în cadrul proiectului intitulat Atlasul lingvistic moldovenesc (ALM), din care au apărut, între 1968-1973, un număr de patru volume. Dar, date fiind și evenimentele la care ne-am referit deja (cf. § 4.1), specialiștii de la Institutul de Lingvistică al Academiei de Științe a Moldovei au reevaluat întreprinderea lor de valorificare din perspectiva geografiei lingvistice regionale dacoromânești a epocii, încadrând volumele publicate începând din 1993, în seria "Atlasul lingvistic român, pe regiuni", cu următorul titlu: Atlasul lingvistic român pe regiuni. Basarabia, Nordul Bucovinei, Transnistria, de la vol. I, 1993, până la vol. IV, 2002-2003, realizate direct de Vasile Pavel, respectiv avându-l pe acesta în calitate de redactor coordonator.

4.4.2. Semnificația noului titlu a fost prezentată prin proiecție de apartenență genealogică dialectală și din perspectiva practicilor cartografierii lingvistice. Selectăm câteva idei și enunțuri ilustrative, din cuvântul înainte la volumul I din ALRR.Bas.Bucov.Trans. (sigla atlasului) semnat de Vasile Pavel. Mai întâi, se observă că vechea denumire, "Atlasul lingvistic moldovenesc" era improprie, deoarece rețeaua de puncte de anchetă cuprinde și localități din așa-numita "Transcarpatie", din Ucraina, în care se vorbesc graiuri aparținând subdialectului maramureșean (având 
răspândire teritorială preponderentă în Maramureș, provincie istorică românească). Dar, chiar trecând peste aceasta, prin determinantul moldovenesc, din titlu, creându-se opoziția cu român (din titulatura „Atlasul lingvistic "), se producea și legitimarea „limbii moldovenești” (Pavel 1993: 6). Prin noul titlu (un atlas al graiurilor din Basarabia, Bucovina de nord și din Transnistria), date fiind, de exemplu, atlasele graiurilor din Banat sau din Maramureș, se pune în evidență o realitate lingvistică: lucrarea „face parte din seria acestor atlase regionale", complementaritate care, de altfel, ține de filiația chestionarelor utilizate în anchete, de sistemul de transcriere fonetică adecvat limbii române, având obiectivul de a adânci cunoașterea "dacoromânei vorbite", prin raportare la rețeaua de puncte a atlasului Weigand, a "Atlasului lingvistic român" etc. (ibidem, p. 7, 8).

4.4.3. Din această largă perspectivă, punctul de vedere al dialectologilor moldoveni de la Chișinău și opțiunea lor se verifică prin compararea hărților ALM și ALRR.Bas.Bucov.Trans. cu cele ale „Noului Atlas lingvistic român pe regiuni. Moldova și Bucovina" și, mai ales, prin racordarea firească a rezultatelor de pe hărțile atlaselor „moldovenești” la hărțile "Atlasului lingvistic român pe regiuni. Sinteză" (vol. I, 2005, vol. II, 2012). Complementaritatea „demonstrează, în ansamblu, unitatea limbii române, expresie a viabilității românismului pe întreg arealul romanic nord-dunărean" (Pavel 1993: 8). Și iată aplicarea acestei perspective atunci când graiurile moldovenești din nord-estul Republicii Moldova sunt analizate „în cadrul dialectului dacoromân”, cu evidențierea trăsăturilor comune ale acestora $\mathrm{cu}$ graiurile maramureșene, dar și $\mathrm{cu}$ graiuri moldovenești „insulare și marginale” (Spînu 2009: passim; vezi, la p. 116117, o critică a punctului de vedere Udler, din lucrarea citată anterior).

Excurs 6. Din perspectiva posibilelor implicații, să nu pierdem din vedere faptul că, în felul acesta, cu mijloace specifice, tehnice, este admisă, indirect, și unitatea teritorială dacoromânească, inclusiv din perspectiva realității unității statale. Nu este vorba de un program $a d-h o c$, dar faptul nu este de neglijat dacă ne raportăm la rolul hărții Weigand privind teritoriile de limbă română, la care ne referim în continuare.

5. Revenind la problema creării statelor naționale din Europa, în urma destrămării imperiilor austro-ungar și țarist, după hotărâri ale Conferinței de Pace de la Paris (1919-1920) și prezentând doar esențialul, trebuie să amintim faptul că o condiţionare lingvistică a noii entităţi statale se încadra în precepte privind existența unei tradiții culturale, a unei psihologii populare comunitare.

5.1. Acestor exigențe, delegația română le-a răspuns, documentar, prin prezentarea, printre altele, a lucrării, monumentale, a lui Iuliu Zanne, 
„Proverbele românilor din România, Basarabia, Bucovina, Ungaria, Istria și Macedonia" (10 volume, tipărite între 1895 - 1912), a colecției revistei "Convorbiri literare", cu apariție începând din 1867, și a unei lucrări de geografie lingvistică a profesorului german Gustav Weigand, intitulată Linguistischer Atlas des dacorumänischen Sprachgebietes („herausgegeben auf Kosten der rumänischen Academie in Bukarest von Prof. Dr. Gustav Weigand, Leipzig, Johann Ambrosius Barth, 1909"). Din acest "Atlas lingvistic al teritoriului dacoromân", a interesat, în mod deosebit, harta de încheiere (67), cu titlul Völkerkarte des rumanischen Sprachgebietes (așadar harta etnică a teritoriului lingvistic românesc), pe care o reproducem (Harta 1).

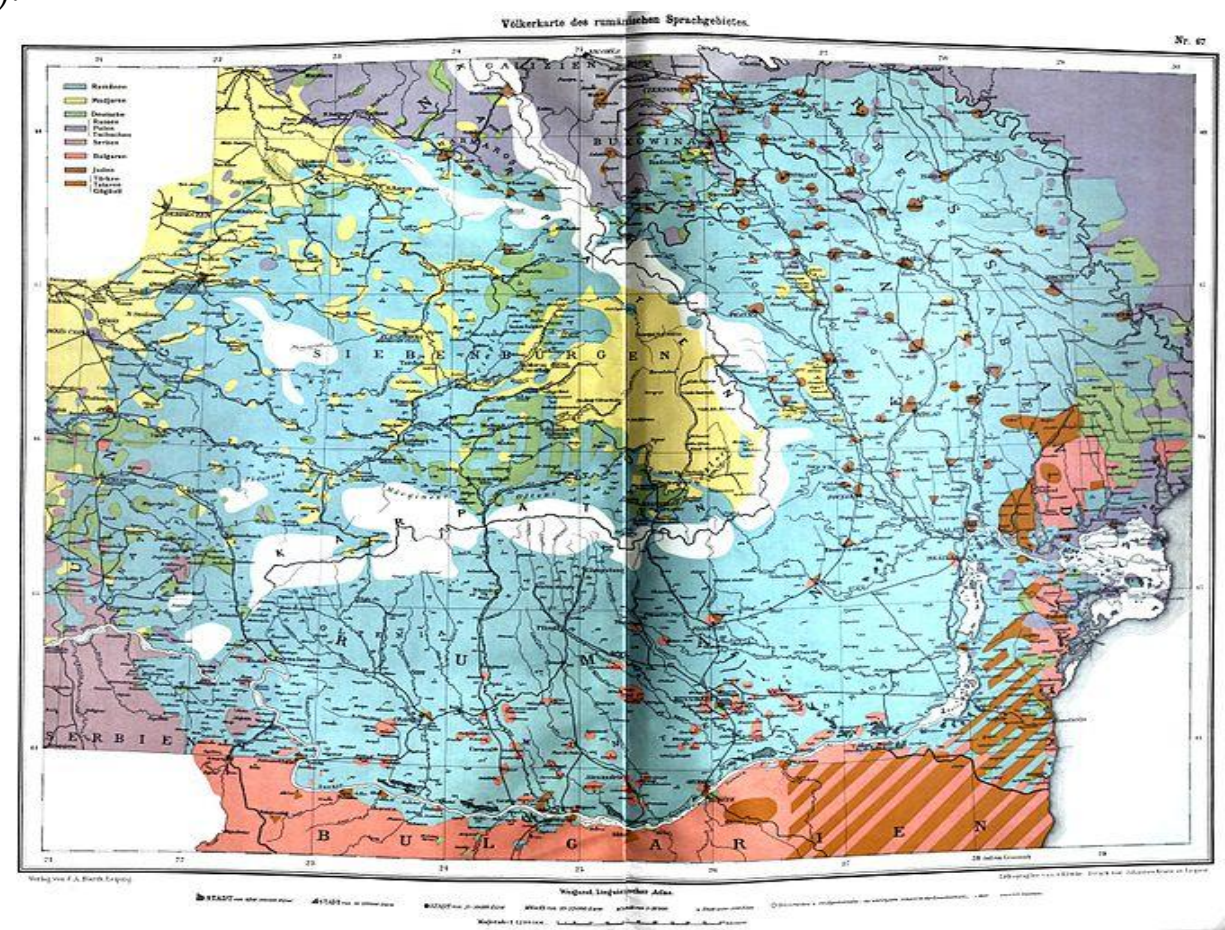

\section{Harta 1}

Pe harta lui Weigand apar marcate toate zonele locuite de români și în care se vorbește limba română (în care a făcut anchete Weigand) din arealul cuprins între Dunăre, sud-vestul Banatului românesc, câmpia Tisei, Carpații nordici, bazinul fluviului Nistru, respectiv reprezentând Dobrogea, fără a omite marcarea spațiilor din interior în care se vorbesc alte limbi (maghiara, dialecte germane, bulgara, ucraineana și turca; pentru prezentarea zonelor populate de alte etnii, cf. Coroliuc 2013: 319-320). Această hartă, folosită la Conferința de Pace de la Paris (cf. Arvinte 1992- 
1993 A: 41) pare că ar fi fost... orientată din perspectiva trasării granițelor de sud-vest şi de nord-vest ale României, în lipsa unor alte delimitări, anterioare, în zonele respective.

5.2. Este cunoscut rolul, deosebit, al geografului francez Emmanuel de Martonne (1873-1955), studios și bun cunoscător al spațiului carpatic, pentru trasarea granițelor României de după primul război mondial (și ale Poloniei, dar și ale statelor sud-dunărene), în calitate de expert al Comitetului de studii de pe lângă Conferința de Pace de la Paris. Este bine cunoscută harta sa consacrată arealului european la care ne-am referit, dar, pentru propunerile înaintate guvernului francez, în ceea ce privește România, harta Weigand a constituit un material documentar de prim rang.

5.3. Iată, aşadar, un anumit tip de lucrare de geografie lingvistică, de interes primar dialectologic, care a venit în sprijinul cunoașterii unității naționale românești.

6. Cea mai importantă lucrare de același tip a constituit-o Atlasul lingvistic român (ALR), cu publicații începând din 1938, atlas pe care Sextil Puşcariu 1-a proiectat având în vedere, însă, tocmai salvgardarea trăsăturilor specifice graiurilor populare românești, din perspectiva schimbărilor, la acest nivel, ce urmau să se petreacă datorită condițiilor aparte de manifestare a influenței limbii literare. Demersul științific a avut însă urmări mult mai complexe, unele neașteptate probabil, pe diferite planuri.

6.1. Iată prezentarea problemei la care ne-am referit:

„Prin întregirea României după marele război, limba noastră trecea printr-una din cele mai mari prefaceri din cursul întregii sale dezvoltări. Limba din Țara Veche și mai ales limba Capitalei pătrundea triumfătoare în provinciile nouă; ici și colo se petrecea și fenomenul invers: intrau în limbă cuvinte și expresii din Ardeal. Procesul acesta deosebit de interesant din punct de vedere lingvistic trebuia surprins în toiul desfășurării; în afară de aceea, limba trebuia fixată pe hărți înainte de a-și pierde cele mai interesante din provincialismele sale" (Pușcariu 1938: 7-8; pentru o proiecție de ansamblu, cf. Dumistrăcel 1978: 3436).

Anchetele pentru Atlasul lingvistic român I (seria Sever Pop) și Atlasul lingvistic român II (seria Petrovici) s-au desfășurat între anii 1929 - 1938, rețeaua ALR I cuprinzând 301 puncte de anchetă (a căror dispunere apare pe Harta 2), iar cea a ALR II 85 de puncte.

6.2. Dar, dincolo de cunoașterea specificului graiurilor limbii române (din punct de vedere fonetic, gramatical și lexical), u n i t a t e a, deosebită, a dacoromânei, prin comparație cu alte limbi romanice (cf. Dumistrăcel 
1978: 28-35; vezi și, supra, Excurs 3 și § 2.3.3), a fost pusă în evidență de hărțile ALR și în ceea ce privește vocabularul unor domenii onomasiologice cum sunt, în special, cele care fac obiectul volumului Pop 1938 (Părțile corpului omenesc), respectiv al primei părți din volumul Petrovici 1940 (Corpul omenesc, boale /și termeni înrudiți). Evident, în cele ce urmează nu vrem să trecem cu vederea existența, mai ales în ceea ce privește lexicul, a diverse deosebiri pe terenul dacoromânei, dar cercetarea obiectivă impune prezentarea specificului și a efectelor, pe ansamblu, a acestor deosebiri, $\mathrm{cu}$ referire, mai întâi, la cele străvechi, pornind de la teoria „valurilor” de „reromanizare" a teritoriului dacoromânesc, formulată de Alexandru Philippide, lingvist ieșean ce are în vedere un dialect "sudic", cuprinzând graiurile din Muntenia - Oltenia, sudul Transilvaniei și sudul Dobrogei, și altul nordic, reprezentând graiurile din Banat, Crișana, partea de nord a Transilvaniei, din Maramureș, Bucovina și din Moldova-Basarabia, pentru ca, apoi, să dăm curs prezentării semnificației altor diferențe, inclusiv ale celor dintre subdiviziuni caracteristice celor două areale.

Excurs 7. Mai întâi, o punere în gardă liminară: punctul de vedere Philippide privind structura dialectală a dacoromânei (după Originea românilor, I-II, 19231928) acceptat, principial, de alți lingviști (printre care semnificativă este poziția lui Em. Vasiliu 1968) a făcut obiectul unor contestații din perspectiva apărării "continuității" și a "prioritățiii" teritoriale a românilor în spațiul geografic actual al României, dintre care numeroase alături cu esența tezei Philippide. Pentru Philippide, peste teritorii (restrânse) de continuitate din fosta Dacie, românii din sudul Dunării s-au deplasat spre nordul fluviului de la începutul secolului al VII-lea până în prima jumătate a celui de al XIII-lea. De altfel, trebuie să precizăm faptul că, pentru analiza evoluției istorice și a structurii dialectale a limbii române, Philippide a utilizat și informații din studiile lui Weigand asupra dialectelor din sudul Dunării, ca şi rezultatele anchetelor acestuia de pe teritoriul dacoromânesc, publicate inițial în diferite volume din "Jahresbericht des Instituts für rumänische Sprache /Rumänisches Seminar/ zu Leipzig", între anii 1896 şi 1902, şi, apoi, în Linguistischer Atlas des dacorumänischen Sprachgebietes - aspectele fonetice (cf. Dumistrăcel 2009b: 33-34). Pentru o prezentare generală a teoriei fondatorului "școlii lingvistice de la Iași”, cf. Arvinte 2006: passim).

6.2.1. Mai întâi, unitatea dacoromânei pusă în lumină de hărțile ALR. Ne limităm doar la situația lexicului privitor la domenii la care ne-am referit anterior, cu extensie asupra altor termeni din vocabularul uzual, aparținând fondului lexical de bază. Pe diferite hărți din ALR I, în toate cele 301 puncte de anchetă s-au înregistrat exclusiv (aşadar nu există sinonime pentru) termeni cum sunt creieri, ochi, piele, sânge, picior, măsea, dinte, piept, 
deget, unghie, genunchi, ureche, inimă; cărunt, sănătos; beau, mănânc, iau, țin, spun, visez; mă doare, tuşesc.

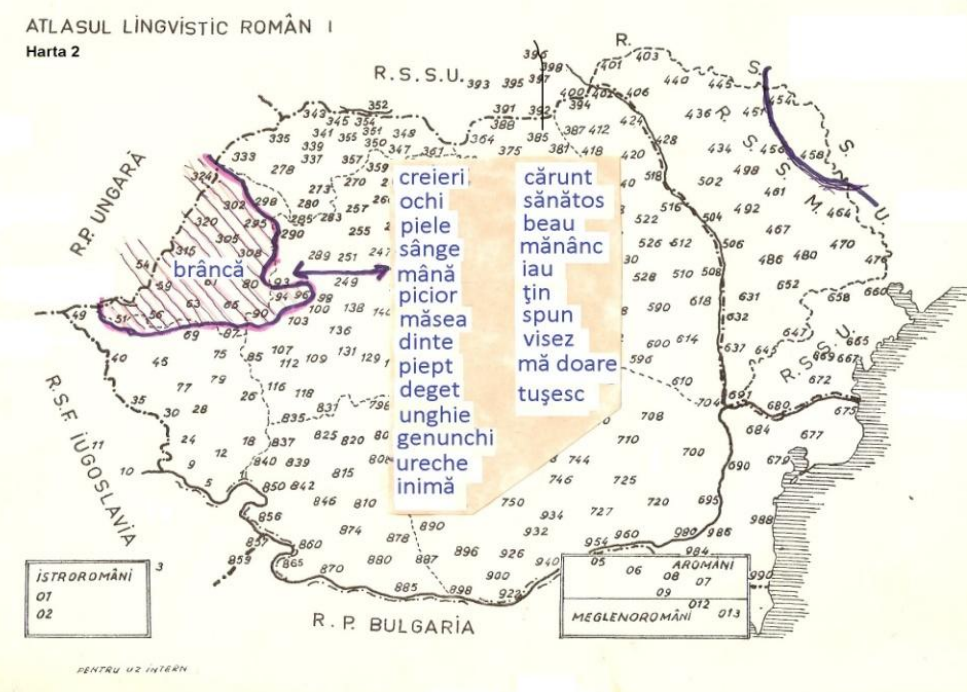

\section{Harta 2}

Excurs 8. Observații generale: pe hărțile respective, dar şi pe cele care urmează, graiurile din Moldova dintre Prut și Nistru se încadrează perfect în arealul dacoromânesc. Pe de altă parte, conturul cartografic al dacoromânei coincide $\mathrm{cu}$ ariile marcate de Weigand pentru ceea ce lingvistul german a numit "dacorumänische Sprachgebiete" (vezi, infra, și Hărțile 2, 3, 4, Пpentru aceleași situații). Nu stăruim asupra originii și semnificației cuvintelor la care ne referim aici; am consultat (și pot fi consultate) seriile DA (1913-1940) și DLR (1965-2010) ale Dicționarului limbii române al Academiei Române. Am încercat să aprofundăm explicațiile etimologice şi semantica unor termeni de substrat în cuprinsul articolelor Dumistrăcel 1989a, Dumistrăcel 1989b, Dumistrăcel 1991, Dumistrăcel 1995a.

6.2.2. Față de cele afirmate anterior, selectăm excepții caracteristice.

a) Complementar ariei majoritare mână, în cea mai mare parte a Crișanei s-a notat termenul brâncă, cu sensul 'mână, ca uz arhaic, o relicvă față de utilizarea generală mai veche a termenului cu același sens în dacoromână, dovedită de păstrarea substantivului în expresiile $a$ da brânci, a cădea în brânci și chiar de circulația generală a verbului (a) îmbrânci. Pe Harta 2, am reprezentat circulația generală în graiurile limbii române a termenilor enumerați mai sus, la care am putea adăuga numeroși alții. 
b) Acelaşi statut cu brâncă are termenul, de origine latină muiere (cf., supra, § 2.1), folosit încă în anii anchetelor pentru ALR într-o arie tot vestică, dar mai extinsă în raport cu brâncă, spre a numi aceeași noțiune pentru care în restul teritoriului dacoromânesc s-a notat termenul (tot de origine latină) femeie (sinonimul regional boreasă, notat în graiurile din câteva localități din centrul Transilvaniei, nu este semnificativ pentru discuția de față); cf. Harta 3.

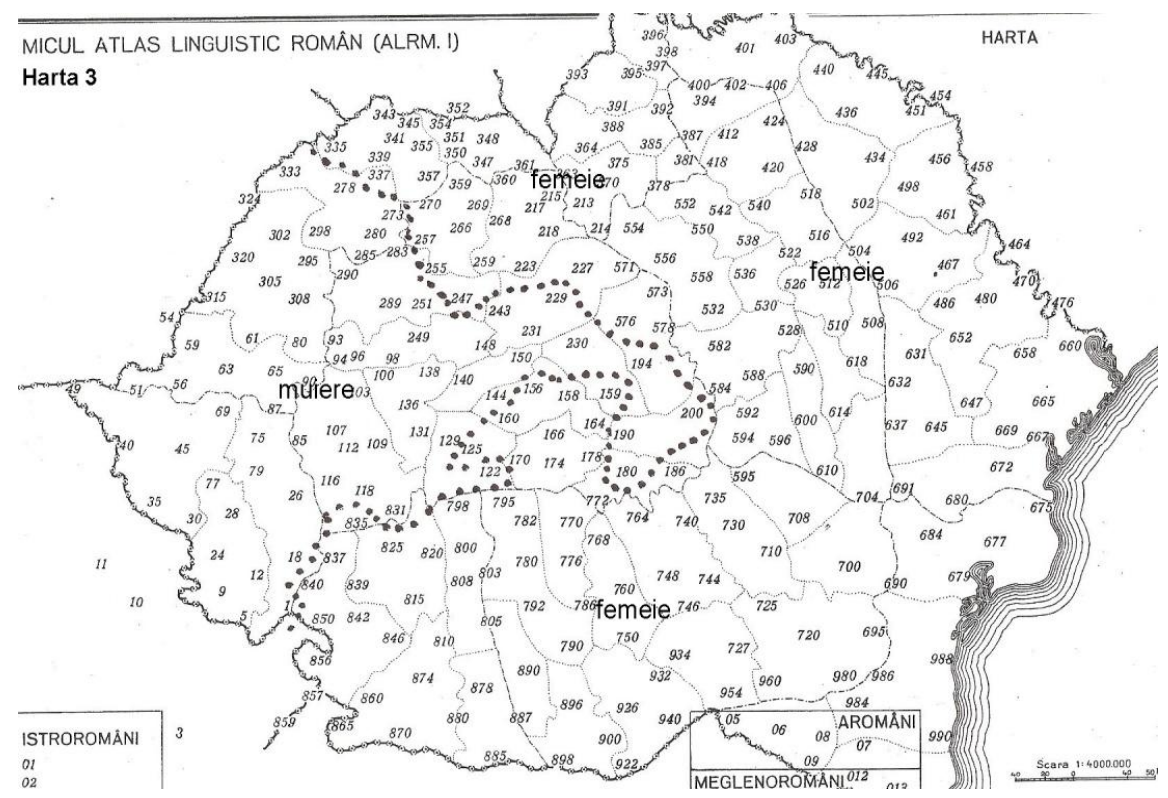

7. Indiferent dacă acceptăm sau nu punctul de vedere Philippide privind, să-i zicem, „re-romanizarea” teritoriului dacoromânei („reimigrare" la Tagliavini), inclusiv explicațiile lingvistului ieșean privind popularea părții nordice a actualei Românii printr-un „val banatotranscarpatin”, iar a părții sudice prin „valul transdunărean”, numeroase hărți din atlasele lingvistice românești prezintă o repartizare bipartită de această factură. Ariile lexicale (în primul rând) nordice deosebite de cele sudice opun termeni de mai multe categorii de origini, mai întâi de tipul latină vs. latină; latină vs. autohtonă, iar, apoi, latină vs. slavă, și, într-o situație aparte din punctul de vedere al istoriei limbii române, ariile de opoziție latină vs. maghiară. Acest tip general de distribuție teritorială a făcut obiectul unei secțiuni din studiul nostru consacrat specificului dialectal al dacoromânei din perspectivă romanică (Dumistrăcel -Hreapcă 2009a), după care selectăm exemplele din secțiunile ce urmează. Menționăm că, în 
continuare, prezentăm doar exemplificări ale cazurilor puse în discuție și că referințele privind variația diatopică au în vedere situația din graiuri din perioada anchetelor pentru ALR.

Excurs 9. Pentru paralelisme ale unor cuvinte de proveniență autohtonă cu elemente de origine latină, având, așadar, aceeași repartiție teritorială, bipartită, cf., infra, § 7.2, cu trimitere la un studiu referitor la semnificația ariilor regionale ale unor elemente autohtone din vocabularul limbii române (Dumistrăcel 1989a).

7.1. Există opoziția, de complementaritate, dintre aria nordică dacoromânească $(\mathrm{N})$ și cea sudică (S) pentru elemente (forme) diferite de origine latină (în ambele arii), cum sunt, printre altele

$$
\begin{aligned}
& \text { curechi }(\mathrm{N}) \text { vs. varză }(\mathrm{S}) \text {; } \\
& \text { moare }(\mathrm{N}) \text { vs. zeamă de varză }(\mathrm{S}) ; \\
& \text { rărunchi }(\mathrm{N}) \text { vs. rinichi }(\mathrm{S}) ; \\
& \text { genunchi }(\mathrm{N}) \text { vs. g(h)enuchi }(\mathrm{S}), \\
& \text { mănunchi }(\mathrm{N}) \text { vs. mănuchi }(\mathrm{S}),
\end{aligned}
$$

opoziții reprezentate pe Harta 4 (mai puțin pentru genunchi - g/h/enuchi și mănunchi - mănuchi), hartă redactată, ca și în cazul unora ce urmează, pornind de la viziunea și reprezentări grafice de la Pușcariu 1936, Pușcariu 1940 și Cazacu-Todoran 1965.

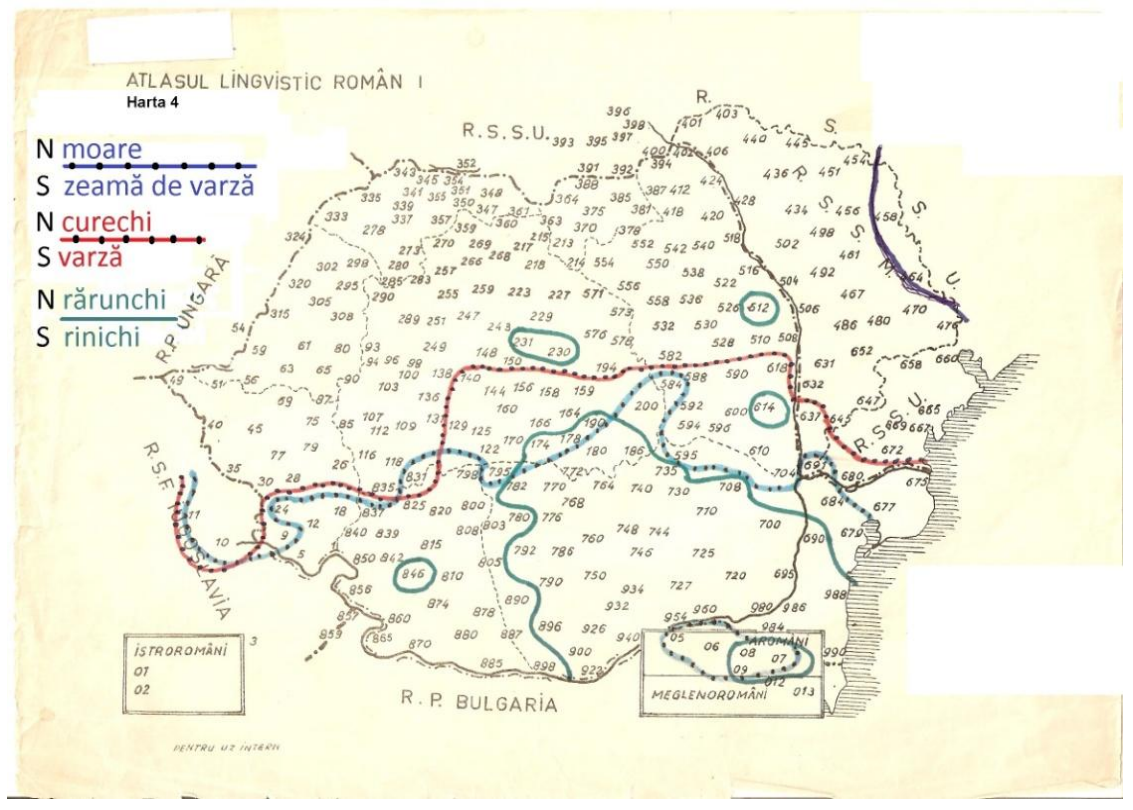

Harta 4 
7.2. Opoziția acelorași arii, pentru elemente de origine latină $(N)$, față de elemente din fondul autohton $(S)$ poate fi ilustrată prin cazurile reprezentate pe Hărțile 5 și $\mathbf{6}$ :

pântece (pâncete), foale (N) vs. burtă (S);

cute (N) vs. gresie (S), cu interferările arcer și piatră (nesemnificative tematic).

Excurs 10. Aceluiași grup îi poate fi adăugată, cu mai puțină pregnanță documentară, opoziția dintre june 'mire', de origine latină, dintr-o arie nordvestică restrânsă, și termenul, curent în aria sudică, ginere (și, pe terenul limbii române, ginerică) cu sensul 'mire; termenul ginere este de origine latină, dar sensul cu care este întrebuințat în graiurile sudice este prezentat drept rezultatul unui calc după un termen tracic, având dubla semnificație /a/ nume purtat de soțul unei femei în raport cu părinții acesteia' (singura semnificație a termenului ginere în aria nordică și a etimonului acestui termen, lat. gener) și /b/ 'nume purtat de bărbat în ziua sau în preajma căsătoriei sale'. Un cadru general, probabil ca influență tracică: ambele semnificații citate mai sus sunt

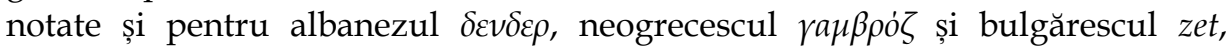
descendenți, ca și lat. gener, ai unui radical indo-european ĝgem(e)- 'a se căsători', cu referire la înrudirea prin alianță; derivatele din limbi indo-europene au fost interpretate, paralel, ca reflectare a "matriarhatului" (cf. Dumistrăcel 1995: 323, cu trimitere la Walde-Pokorny 1973 (1930): 574-575).

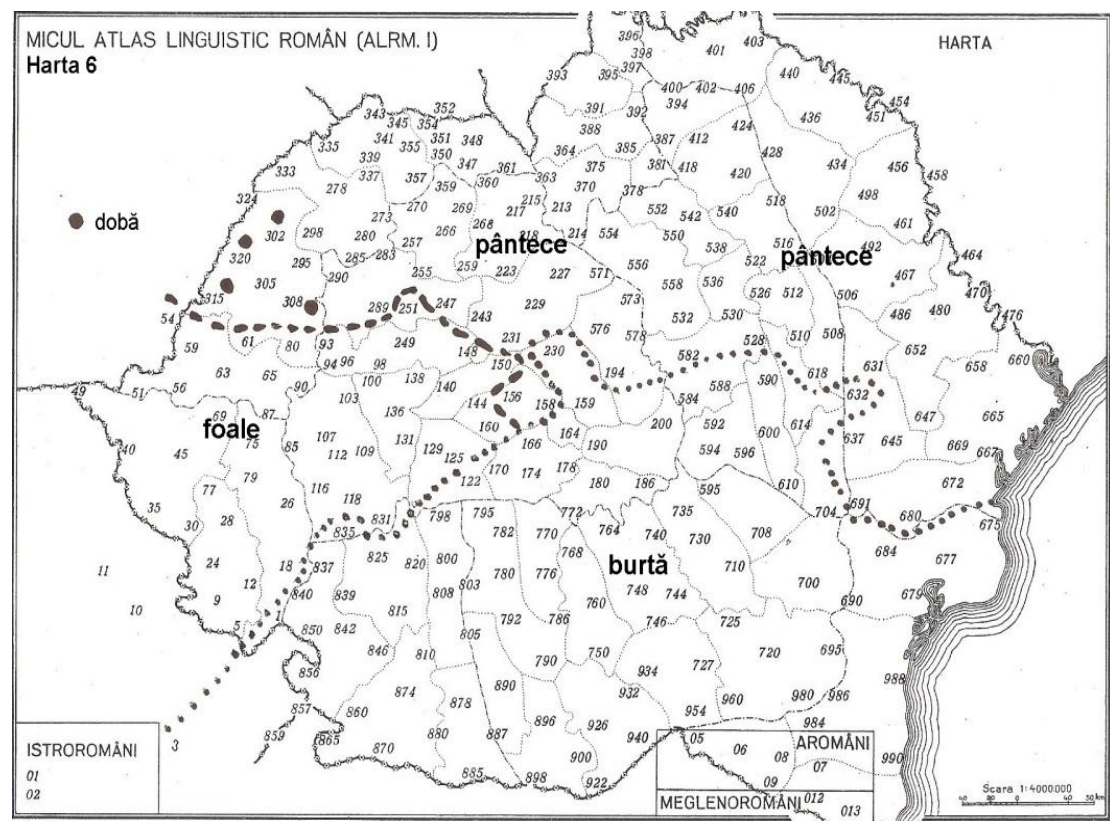

\section{Harta 5}




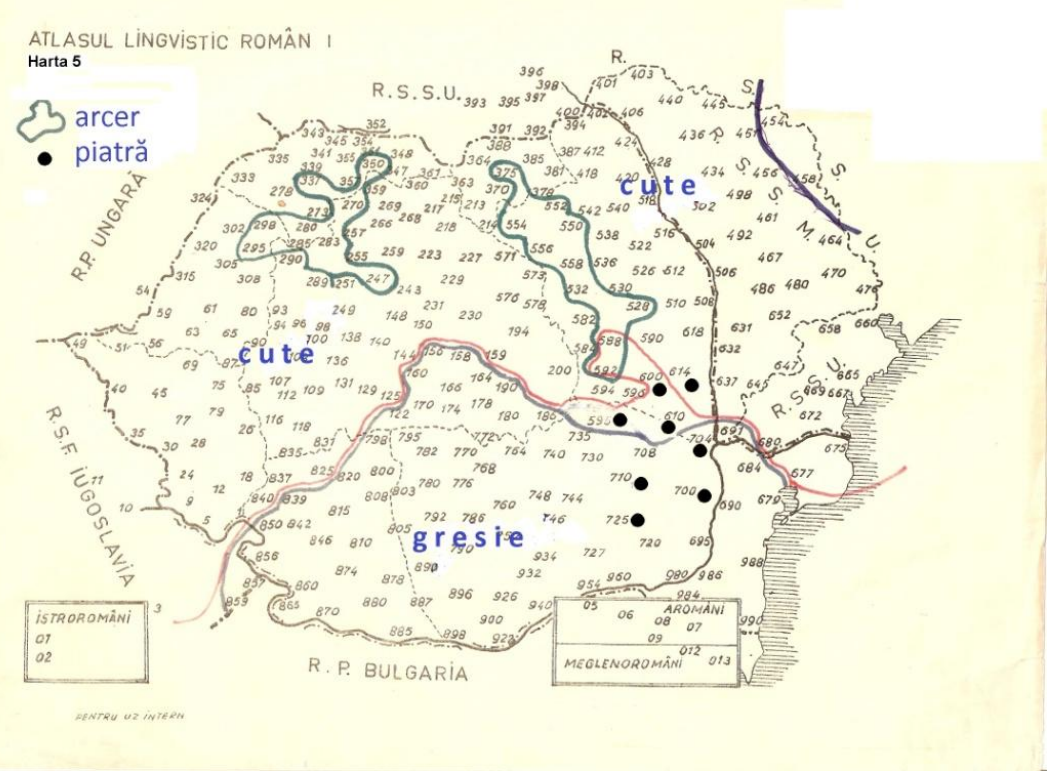

\section{Harta 6}

7.3. Opoziția celor două arii în discuție poate fi constatată și în ceea ce privește elemente aparținând stratului (latin) al limbii române în raport cu elemente ale adstratului slav, acestea din urmă fiind dublete ale termenilor de origine latină atât în aria sudică $\left(\mathrm{sl}^{1}\right)$, cât și în cea nordică $\left(\mathrm{sl}^{2}\right)$ :

$\mathrm{sl}^{1}$ sudoare $(\mathrm{N})$ vs. (în)nădușeală (S);

nea (N, deja într-o arie limitată) vs. zăpadă (S);

coardă $(\mathrm{N})$ vs. strună $(\mathrm{S})$

$\mathrm{sl}^{2}$ ciolan $(\mathrm{N})$ vs. os $(\mathrm{S})$.

8. Din perspectiva istoriei limbii române o problemă aparte o reprezintă elementul de substrat, respectiv, prezența, în vocabularul dacoromânei, a cuvintelor din dialecte ale limbii traco-dacilor, aflați în stadiul societăţii tribale, problemă pe care am abordat-o in special în studiul consacrat semnificației ariilor regionale (lexicale și semantice) ale unor elemente autohtone din vocabularul limbii române (Dumistrăcel 1989a), de la care pornim, în general, pentru discuțiile care urmează:

8.1. Dacă, în primul rând, cunoașterea diferitelor situații în care se află, în arealul nordic și în cel sudic al dacoromânei, cuvintele de origine latină ar constitui o condiție suficientă pentru a admite teoria „valurilor" a 
lui Philippide, situația se complică, măcar parțial și aparent, dacă ne referim la tabloul de ansamblu al termenilor moșteniți din substrat.

8.1.2. Am constatat deja opoziţia cu elemente de origine latină în cazurile burtă și gresie, ambele specifice arealului sudic (cf., supra, § 7.2). Tot arealului sudic, după cercetări particulare (B.P. Hasdeu, Al. Rosetti, I.I. Russu, I. Fischer, sintetizate în articolul nostru citat anterior), îi aparțin termeni cum sunt barză (în N cocostârc, creație pe terenul limbii române), ghionoaie (în N ciocănitoare, de asemenea creație pe terenul limbii române, de pus în relație însă cu circulația termenilor cioc vs. plisc), ghiuj/ghij, față de vâjj, în Transilvania, opoziție discutată încă de Hasdeu etc.

8.1.3. Arealul nordic se caracterizează, lexical, în special prin prezența lui mire, cu sensul 'nume purtat de bărbat în ziua nunții sale', termen devenit literar, și, din alt punct de vedere, prin accepțiile aparte ale cuvintelor la care ne referim în secțiunea următoare.

8.2. Există, totuși, ca și în cazul cuvintelor de origine latină, termeni comuni atât arealului nordic, cât și celui sudic: abur, buză, copac, ghimpe, mugure, pârâu, vatră etc., când ne confruntăm cu o situație comparabilă cu folosirea, pe tot teritoriul dacoromânesc, a termenilor de origine latină din seria creieri $\rightarrow$ tușesc, înfățișată pe Harta 2 (supra, § 6.2.1). Pe de altă parte, există cazuri în care se constată sensuri diferite, în arealul nordic, față de cel sudic, al aceluiași cuvânt de substrat; în această situație se află, de exemplu, termenii argea (cf. Dumistrăcel 1989b: passim, la care trimit Sala-Ionescu Ruxăndoiu 2018: 314), dar și (a) ciupi, baltă, gușă sau rânză (cf. Dumistrăcel 1989a:passim),

8.3. Importanța aparte a elementelor autohtone privind discuţia de față constă în faptul că, existând grupuri de graiuri din aria sudică, respectiv de grupuri de graiuri din aria nordică al căror vocabular se individualizează prin anumite elemente de substrat (lexic, semantică), putem admite că respectivele areale, străvechi, reprezintă mărturii ale continuității populațiilor romanizate pe teritoriul locuit de vechii geto-daci la nord de Dunăre (punctul nostru de vedere fiind acceptat în SalaIonescu-Ruxăndoiu 2018: 298-299). Ideea în discuție este întărită de existența, paralelă, a arealelor nordic și sudic ce se caracterizează prin elemente specifice de origine latină. Așadar, putem admite că peste aceste vechi areale s-au putut suprapune graiuri din sudul Dunării, ca rezultat al celor două „valuri” de reimigrare intuite și argumentate de A. Philippide. Acceptând mărturia acestei dinamici (lingvistice) a etnogenezei și admițând continuitatea populației romanizate pe teritoriul carpato-dunărean, în sprijinul interpretării în discuție putem invoca, de asemenea, existența și păstrarea, peste evenimentele de după părăsirea Daciei sub împăratul 
Aurelian, dar, pe cursul inferior al Dunării, și în epoca împăratului Constantin cel Mare, a unui anumit statut al acelor "zone nucleu de romanizare” („Kerngebiete”) la care s-au referit Ernst Gamillscheg și Günter Reichenkron, invocate apoi de Emil Petrovici (cf. Arvinte 2003: passim).

Excurs 11. Rolul, important, al atlaselor lingvistice românești pentru cunoașterea istoriei limbii trece de problemele limbii române; o dovedesc, printre altele studiile lingvistului german Günter Reichenkron, asupra semnificației ALR pentru cunoașterea istoriei limbilor slave (Reichenkron 1940a), respectiv pentru lingvistica maghiară și turcă (Reichenkron 1940b).

9. Pentru ansamblul discuției cu privire la „unitatea” limbii române, pornind de la raportarea la cele două "dialecte" ale idiomului romanic nord-dunărean (după Philippide), trebuie să punem în discuție problema împrumuturilor lexicale din dacoromână, începând chiar cu primul mileniu al erei noastre, dar la diferite niveluri, problemă care se pune cu acuitate.

9.1. Mai întâi, observăm opoziția bipartită ce a făcut obiectul unor secțiuni anterioare, în ceea ce privește influența unui strat lexical nou din vocabularul limbii române, cel al limbii maghiare. Semnalăm această opoziție pentru elemente de origine latină din arealul sudic în raport cu împrumuturi din maghiară în arealul nordic, ca una dintre cele mai vechi influențe de contact, în aria nordică, cu populații vorbind alte limbi, stabilite pe teritoriul dacoromânei:

$m a i(\mathrm{~N})$ vs. ficat (S);

(a) sudui (suduitură, sudalmă; N) vs. (a) înjura (înjurătură; S).

9.2. După ce, pe baza materialului ilustrativ din secțiunile precedente, prezentând opozițiile termenilor discutați, am ilustrat existența celor două arii complementare ale dacoromânei pentru perioada formării acesteia, în secțiunea prezentă încercăm schițarea unei anumite funcționalități lingvistice pentru aria nordică. În spațiul caracterizat deja prin anumite trăsături lingvistice, deosebite de cele din sud, trebuie să avem în vedere mișcarea unor populații care au avut contact direct cu vorbitorii limbii maghiare pentru a explica propagarea împrumuturilor din această limbă până la limitele estice ale arealului nordic al dacoromânei. De aici, putem trage anumite concluzii.

10. Ca observații de retrospectivă imediată, suntem obligați față de cititori, în primul rând, să precizăm faptul că, în toate aprecierile noastre, avem în vedere un principiu coșerian, aplicabil la problema 
împrumuturilor ce caracterizează profilul limbii române, anume primatul istoriei, cu aplicație directă și la această analiză ocazionată de centenarul României Mari; ne referim la fraza de încheiere a studiului „Vom Primat der Geschichte", ce rezumă un punct de vedere al lui Hermann Paul, din Principiile de istoria limbii: "Sprachwissenschaft ist tatsächlich Sprachgeschichte": însăşi simpla descriere a limbii, chiar dacă nu este decât o istorie parțială și provizorie (Coserio 1980: 145).

10.1. În această ordine de idei, avem în vedere, în primul rând, o precizare tehnică pentru care trimitem la Louis Deroy, indoeuropenist, autorul celei mai importante monografii dedicate împrumutului lingvistic. Acest specialist a făcut observația că, în mod curent, când se vorbește de împrumuturi, trimiterile sunt la lexic, deși numeroase alte secțiuni ale limbii pot fi luate în discuție din acest punct de vedere: sunete, accentuarea, trăsături morfologice, sensuri, construcții sintactice (Deroy 1956: 17). De fapt, în afara faptului că, invocând acest fapt, am încercat să ne punem la adăpost față de obiecții de viziune perfecționistă, îi suntem îndatorați lui Deroy pentru o caracterizare (aparent) surprinzătoare a limbii române, ca fiind un "paradis al împrumutului”, ce ar putea submina caracterizarea acesteia drept „unitară”, dar importantă și întrucât autorul explică această bogăție prin condițiile geografice şi istorice în care au trăit vorbitorii românei: vecinătatea $\mathrm{cu}$ vorbitorii unor limbi slave, contactul cu limba maghiară, turcă şi cu greaca, așadar prin împrejurări de ordin istoric și geopolitic:

"Certaines langues sont des paradis de l'emprunt. On voudrait pouvoir s'attarder, par exemple, au roumain, qui doit à son histoire et à sa situation géographique particulière tant d'éléments slaves, hongrois, turcs et grecs" (Deroy 1956: 67).

Autorul se referă, apoi, pentru limba literară, la împrumuturile din franceză; printre neologismele citate: curaj, egoism, funcționar, milionar, pension, prințesă, salon, simplu, soldat, toaletă ,et une foule d'autres gallicismes".

10.2. Astfel, diversificarea lexicală a limbii române este un efect al evoluției sale istorice mai ales în epoca modernă, iar acest aspect a fost pus în lumină de o descriere istorică rațională, plasată chiar sub semnul geografiei lingvistice. Ne referim la un studiu al lui L. Gáldi consacrat unor probleme de geografie lingvistică pentru română în secolul al XVII-lea. În ceea ce privește lexicul dacoromânei în epoca de referință, lingvistul maghiar demonstrează că există influențe lingvistice regionale de două categorii, una culturală propriu-zisă, iar alta privind cultura materială. Dacă pentru Principate influența la nivel cultural o reprezintă limba neogreacă, pentru Banat, Crișana, Transilvania și Maramureș influența respectivă o 
constituie, la același nivel, latina savantă, prin filiera limbii germane. Paralel, principalele împrumuturi numind noutățile în ceea ce privește cultura materială sunt, pentru limba din Principate, de origine turcă, iar pentru limba română din provinciile de la nord și de la vest de Carpați sunt de origine maghiară (Gáldi 1938). Un exemplu: catifea (< tc. katifâ), față de barșon (< magh. bársony; o prezentare a studiului la Ciureanu 1940-1941).

10.3. Discutarea acestei probleme impune, așadar, o distincție principială, ținând seama de cele două aspecte puse în evidență și de L. Gáldi: influențe culturale, în sens larg, asupra limbii literare, și influențele la nivelul vorbirii comune, prin contactul românilor $\mathrm{cu}$ vorbitorii altor limbi.

10.3.1. În ceea ce privește primul aspect, trebuie să observăm că limba română (literară), în diferite faze ale evoluției sale, a cunoscut mai multe influențe străine, care s-au succedat, iar din produsul acestora, cu timpul, în limba literară s-au păstrat un număr în general redus de urme, diferit însă de la caz la caz. Au fost pe larg discutate, în timp, efectele slavonismului cultural, apoi, influența neogreacă, cea a limbii franceze, ultima cu rezultate ce au putut fi apreciate, în special prin eliminarea excesului de grecisme, în Țara Veche, și de germanisme, în spațiul transilvan, ca o „re-romanizare” (sau „re-latinizare") a limbii române, după cum, în prezent, este remarcabil împrumutul de anglicisme. Trecând peste momentele de „criză” lingvistică (puseuri de utilizare a grecismelor sau a franțuzismelor, în Principate, a rusismelor, în Basarabia, a germanismelor, în spațiul lingvistic transilvănean), astfel de prezențe diastratice, ca să nu mai vorbim de cele diatopice, fluctuante și trecătoare, nu au avut urmări de slăbire a unității de bază a limbii române.

Excurs 12. O analiză aplicată, pe baza anchetelor pentru ALR, privind ieșirea din uz a termenilor administrativi de origine străină chiar pentru epoca de imediat de după întregirea României Mari, a întreprins Sever Pop, care, în anii 1929-1933, constata, printre altele, înlocuirea, în zona transilvăneană, prin termenul județ, a unor germanisme sau maghiarisme de tipul comitat (germ. Komitat), bețârc (germ. Bezirk), varmeghe (magh. vármegye), după cum neologismul prefect înlocuia nu doar regionalismele șpan și fișpan de origine maghiară (span, fö-ispán) din Transilvania, împrumuturile rusești zemski nacialnic sau voiski nacialnic din graiurile din Basarabia, dar, în Bucovina, şi termenul "tehnic" căpitan cu sensul special aici în discuție, ca și arhaismul ispravnic, în Basarabia. În afară de termenii din acest domeniu (cf. și pretor, față de solgăbirău), alte neologisme luau locul regionalismelor devenite inactuale comunicativ: farmacie (- potică), gară (- ștație), poliță (- vecsăl, valtău), „a da faliment (- a bucta), ziar, gazetă (- uişag, țăitung). Dar nu este vorba numai de neologisme; termenul „regățean” chibrit (de origine turcească) înlocuiește o 
serie întreagă de germanisme şi maghiarisme de tipul moșâni, ghiufe, șvebele, răipelțuri, ținhelțuri, şălitre, din graiurile provinciilor de la nord și de la est de Carpați, respectiv înlocuiește pe țâbric din Bucovina și pe sărnic din Basarabia (Pop 1934: passim).

Şi am încheiat seria cu acest termen pentru că el va fi evocat, apoi, de Eugen Coșeriu, într-un enunț, devenit celebru, cu privire la semnificația reală a regionalismelor de proveniență rusească față cu pretenția ca, pe baza lor, să se susțină existența unei limbi "moldovenești”. În comunicarea Latinitatea orientală, lingvistul își completa argumentarea în acest sens prin fraza "Cu câteva cleioance, cu câteva sărnice și cu niște baistruci nu se face o limbă" (Coșeriu 1994c), împrumuturi din rusă convocate deloc întâmplător: cleioancă înseamnă „mușama”, iar baistruc, „,bastard", numit, în diferite graiuri populare, și buruienar, urzicar, copil de gard etc.

10.3.2. Diferite hărți, în special din volumele ALR II, ilustrează însă un aspect important principial în legătură cu relevanța diatopică a reprezentanții, de la nivelul vorbirii populare, ai „paradisului împrumuturilor". De altfel, trebuie subliniat faptul că dintre numeroasele împrumuturi zonale, în arii diferite din spațiul dacoromânei, unele au fost descoperite abia pe baza anchetelor etnolingvistice pentru ALR I și II și aveau să fie enumerate, alături de arhaisme latinești sau de cuvinte moștenite din substrat, pentru caracterizarea lexicală a „subdialectelor" dacoromânei. În această situație sunt, de exemplu, pentru „subdialectul crișean", alături de brâncă 'mână', „mă caut în oglindă" 'mă uit', cotătoare 'oglindă' (de origine latină), maghiarismele goz 'gunoi în ochi', chefe 'perie', ciont 'os', iar "subdialectul bănățean", în mare, alături de cuvintele moștenite din latină nea 'zăpadă' și foale 'burtă' se distinge prin sârbismele uică 'unchi' golumb 'porumbel' sau arghelă 'herghelie' (Petrovici 1970: 40, 41, cf. și hărțile 3 și 4 din textul respectiv).

11. O schiță de analiză sistematică a straturilor constante ale lexicului dacoromânei și a celor datorate diferitelor influențe din partea unor limbi străine în lexicul dacoromânei vorbite, pe bază de rezultate ale anchetelor pentru ALR I și ALR II, în linia inaugurată de Sextil Puşcariu, aveau să întreprindă Boris Cazacu și Romulus Todoran, propunându-și ca obiectiv „trăsăturile specifice și ariile dialectale" ale limbii române. Pe de altă parte, este concludentă, sui-generis, compararea rezultatelor anchetelor pentru ALR I și ALR II cu cele provenind din anchetele pentru Noul Atlas lingvistic român, pe regiuni, în cazul de față pentru secțiunea privind Moldova și Bucovina.

11.1. Pentru autorii citați, „specificul” lexical al limbii române, pe baza rezultatelor din hărțile ALR, îl constituie, în raport cu alte limbi 
romanice, în ceea ce privește fondul latin, caracterul ei unitar, dar și existența unor diferențe regionale, ca arii bimembre (începând cu moștenirile din latină), și ca arii plurimembre, datorate în special contactelor cu vorbitorii altor limbi. B. Cazacu și Romulus Todoran pun accent pe valoarea funcțională a inventarului sinonimic și subliniază caracterul corelativ al termenilor numind una și aceeași noțiune, din perspectivă diacronică. Astfel este reluată, parțial, tipologia ariilor în general cunoscută de la Pușcariu, la care ne-am referit anterior. Una dintre cele mai concludente hărți din ALR II, serie nouă, privind diferențele lexicale de pe teritoriul dacoromânesc este aceea consacrată termenilor pentru „vopsea (pentru piei)", prezentați sumar, numai sub aspect etimologic: farbă, germanism, în graiurile din Banat (dar și în graiuri din aria nordică transilvăneană), feșteală (și variante), derivat de la verbul (a) fești, de origine maghiară, în Crișana, jumătatea de nord a Transilvaniei și în Maramureș, boia, turcism, în graiurile din Moldova, cel mai răspândit termen fiind vopsea, postverbal de la (a) vopsi, cuvânt de origine neogreacă, pătruns în română prin bulgară, propriu, inițial, graiurilor din Muntenia și Oltenia, din sudul Transilvaniei și Dobrogea; devenit termen literar, este înregistrat și în graiuri din Moldova (vezi Harta 7). Demn de remarcat este faptul că un termen literar, neologism, [culoare], a fost înregistrat doar într-un singur punct, 64, din sudul Crișanei, de la un vorbitor cititor de ziare, care știa puțin și ungurește (Petrovici 1988: 246).

\section{MICUL ATLAS LINGVISTIC ROMIN}

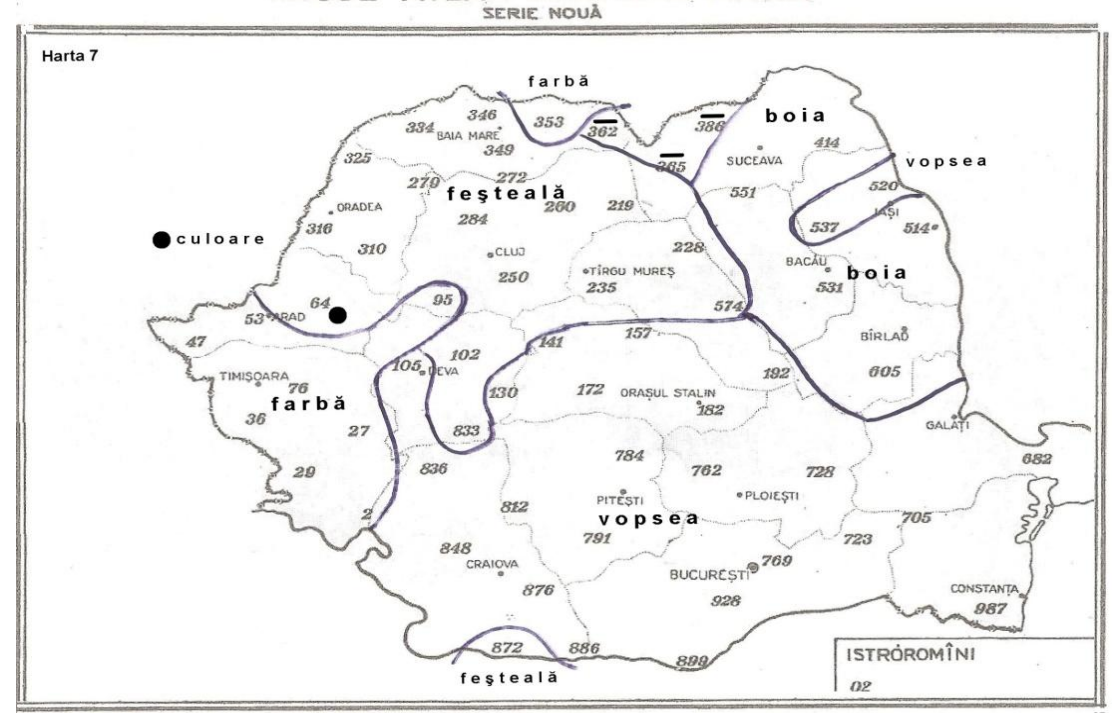

Harta 7 
Excurs 13. Din cauză că, la publicarea volumelor din "seria nouă” din ALR II au fost excluse punctele de anchetă reprezentând graiurile din Basarabia (aceste volume au apărut începând din anul 1956!), pe hărți analitice care preiau materiale din sursele respective, cum este și cea precedentă, nu este reprezentată situația graiurilor de la est de Prut. Dar, în pofida unui decalaj cronologic, putem afirma că termenul boia este caracteristic și graiurilor din această zonă dacoromânească, așa cum se poate constata după hărți din ALRR.Bas.Bucov.Trans., fapt asupra căruia nu insistăm. Aceeași este situația și în ceea ce privește materialul discutat în secțiunea următoare, pentru unii din termeni verificarea fiind posibilă pe baza hărților din volumele ALM.

11.2. Pe hărțile publicate în secțiunile precedente, fără să mai vorbim de ariile "totale" dacoromânești cum sunt cele prezentate pe Harta 2, atunci când constatăm arii complementare nord - sud, delimitarea ariilor „nordice" față de cele sudice se face prin izoglose orizontale, incluzând, în primul tip de arii, spațiul lingvistic basarabean. Aceasta este situația prezentă pe hărțile următoare, după rețeaua ALR I, graiurilor basarabene fiindu-le proprii termeni cum sunt curechi, moare, pântece, cute, sau (fonetismul) rărunchi. Și nu putem fi contraziși atunci când, chiar în absența reprezentării grafice, pe hărți cu rețeaua de puncte din ALR II, serie nouă, atribuim și graiurilor basarabene termeni „nordici” cum sunt cocostârc, mâț̆ă sau altele de același fel.

11.3. Unei asemenea imagini, destul de comodă interpretativ, i se opune, pentru specialiști, realitatea existenței unor diferențieri chiar pe terenul așa-numitului „subdialect” moldovenesc, discutate, în general, în epoci în care Moldova dintre Prut şi Nistru era desprinsă geopolitic din teritoriul Moldovei istorice, studii care se resimt, în fond nemotivat, de această limită. Este vorba de deosebiri între graiurile din jumătatea de nord și cea de sud a Moldovei dintre Carpați și Prut și menționăm faptul că, în cele ce urmează, rezumăm rezultatele unui studiu consacrat semnificației diferențelor dintre rezultatele anchetelor din rețelele naționale ale atlaselor lingvistice românești față de cele din seria atlaselor regionale (cf. Dumistrăcel et alii 2011: passim).

11.4. Asemenea deosebiri au fost semnalate sau analizate începând cu primele abordări științifice ale "graiurilor" moldovenești, de la Ion Nădejde (1884), până la Iorgu Iordan $(1921,1968)$ sau, pentru spațiul de la est de Prut și, sui-generis, venind dinspre exegeza din fosta R.S.S. Moldovenească, de Rubin Udler (Диалектное членение толдавского языка, 1976), deosebiri pentru care, în continuare, ne mărginim la un minimum de exemple ilustrative. Urmând, dinspre sud-vest spre nord-est, pe o linie Tg. Ocna - Adjud - Huși (de fapt, hotarul convențional dintre "Țara de Sus" și 
„Țara de Jos", cu referire la Moldova istorică), o izofonă tipică despărțitoare este aceea care (prezentând simplificat faptele) marchează limita dintre tratamentul fricativelor labio-dentale $f / v+i$ ca fricative alveolo-palatale, $\hat{s} /$ Z, în nord, respectiv ca fricative palatale, $h^{\prime} / y$, în sud (sirir/Z̈ in, față de h'ir/yin, pentru fir/vin), pentru cuvintele cu inițialele fi-, respectiv vi- (ca și pentru cele în care această secvență fonetică este mediană). Graiurilor din sudul Moldovei le mai sunt caracteristice, de asemenea, și alte evoluții pe terenul limbii române, cum ar fi prezența lui $-u$ (final), forme iotacizate ale unor categorii de verbe, varianta negel (față de nigel în nord) etc., dintre care o parte reprezintă porțiuni din areale mai dezvoltate muntenești, respectiv muntenești-transilvănene. Totodată, cu aceeași explicație, graiurile din sud cunosc elemente lexicale diferite față de cele din graiurile nordice, cum ar fi, de exemplu, scul (vs. tort); război / de țesut/ (vs. stative); melc (vs. culbec); porumbel (vs. hulub); coțofană (vs. țarcă); (a) scopi (vs. jugăni); șură / de paie/ (vs. stog); pepene (vs. harbuz); furcă / de lemn/ (vs. țăpoi); uger (vs. pulpă), sau diferențe în ceea ce privește sufixarea: însemnez (vs. însemn); cânepărie (vs. cânepiște) etc.

Excurs 14. Numeroase astfel de situații au fost evidențiate în hărți „interpretative" și în hărți „,sintetice”, realizări grafice plasate alături de hărțile de tip ", analitic" sau în grupaje finale din cele patru volume din NALR. Moldova şi Bucovina (publicate între anii 1987-2014), iar faptele lingvistice de referință sunt convingător ilustrate și de sintezele de tip „material necartografiat” din cuprinsul tomurilor respective, ca și de etno- și sociotextele din cele trei volume de "texte dialectale", apărute ca ",anexe” la Atlas (1993-2002).

În pofida „înclinării” izofonelor și a izogloselor de tipul celor citate, pe direcția sud-vest $\rightarrow$ nord-est, recunoaștem plasarea generală, pe orizontală, a arealelor indicate mai sus, care se înscriu în tipologia generală a delimitării bipartite a teritoriului lingvistic dacoromânesc, inclusiv în ceea ce privește explicația etimologică a sinonimelor (cf. § 7 și 8).

12. Existența unor arii cu delimitare „pe verticală” și semnificaţia acestora. Confruntarea dintre rezultatele înregistrate pe hărți ale atlaselor lingvistice naționale și cele înregistrate pe hărți ale atlaselor regionale, schițată pe baza unor exemple privitoare la graiurile din Moldova și din Oltenia (cf. Dumistrăcel et alii 2011), confirmă existența acelorași fapte lingvistice, recte păstrarea, după aproximativ nouă decenii de la efectuarea anchetelor pentru ALR, a acelorași caracteristici regionale (fonetisme, lexic). Dar, dată fiind amplificarea numărului de localități anchetate pentru aceeași provincie (de exemplu, pentru Moldova și Bucovina numărul respectiv a crescut de la 48 în rețeaua ALR I și 10 în rețeaua ALR II, la 210 în 
rețeaua NALR), informații anterioare ce puteau să pară aleatorii sau neconvingătoare zonal, pe baza anchetelor pentru ALR, nu numai că s-au confirmat, ci au dus la conturarea unor arii noi. În cazul de față, de exemplu, ceea ce putea părea doar apariția unor răspunsuri diferite în puncte din intervalul Carpați-Siret (din vest) față de cele din intervalul Siret-Prut (din est), prin îndesirea numărului de puncte anchetate în ambele spații s-a ajuns la conturarea unor adevărate arii complementare. Este vorba de cazurile, discutate deja în studiul citat, pe care le enumerăm prezentând mai întâi tipul "vestic" în raport cu cel "estic": ouăle /picioarelor/, față de ouşoare, uimă (și subtipuri) 'abcès sous l'aiselle, enflure', față de udmă (și subtipuri), cazuri la care mai putem adăuga fonetismele creier, greier, treier, față de crier, grier, trier, ori gutuie față de gutăie, ca și termenul sucală, față de letcă. Este de subliniat că faptele aparținând ariei „estice” nu caracterizează doar graiurile moldovenești dintre valea Siretului (zona de delimitare a celor două arii) și Prut, ci sunt prezente și în graiurile dintre Prut și Nistru (Dumistrăcel et alii 2011: 223, așadar nu se află în situația de a reprezenta un (potențial) specific lingvistic „basarabean”, respectiv dintre cele care ar putea fi invocate pentru a susține o limbă „moldovenească” deosebită de limba română.

Excurs 15. La nivel microareal, am mai putea vorbi, în spațiul „subdialectului" moldovenesc și de alt tip de arii "verticale", în primul rând cele din zona Bucovinei, una "mozaic", de interferență cu graiuri nord-transilvănene (la Udler, op.cit., grupul de graiuri moldovenești „nordice"), iar, în al doilea rând, graiurile din nord-estul Moldovei de pe teritoriul României, cu influențe lexicale de proveniență slavă de est (hâră 'mătreață', cosie 'toporâște, la coasă', plămân negru 'ficat', ultimul un calc), situații nesemnificative tematic.

13. Observând, mai întâi, faptul că pentru românii din spaţiul transilvănean, în multinaționalul Imperiu Austro-Ungar, nu știm să fi fost formulată vreo pretenție privind existența, aici, a unei alte limbi de factură romanică, înrudită, oricum, cu limba română, orientarea geopolitică și politica lingvistică a Imperiului Rus și, apoi, a fostei U.R.S.S. fiind cu totul alta, încercăm să ne legitimăm afirmațiile proprii referitoare la unitatea limbii române din perspectiva statutului graiurilor românești din Moldova dintre Prut și Nistru și a statutului pretinsei limbi (literare) moldovenești. Susținând punctul de vedere respectiv, ne întemeiem pe cercetarea teoriei domeniului, formulată, în afara celor invocate anterior (§ 2.3 și 4.3), de un Eugeniu Coșeriu, savant originar din Mihăileni - Bălți, și, apoi, ținând seama de punctul de vedere al lingviștilor basarabeni, exprimat mai ales după afirmarea independenței statale a Moldovei, dar și al unor intelectuali basarabeni, scriitori, oameni de cultură și oameni de afaceri stabiliți în 
străinătate, având sentimentul acut al naționalității lor. În ceea ce îl privește pe Magistrul de la Tübingen, trimitem și la studiul Unitatea limbii române planuri şi criterii (2003), iar punctul de vedere al lingviștilor şi al oamenilor de cultură basarabeni, ce refuză excluderea națională și printr-un surogat de limbă, este permanent prezentat și susținut în paginile revistei „Limba română" de la Chișinău, fondată de Ion Dumeniuk, Nicolae Mătcaș şi Alexandru Bantoş, ajunsă în cel de al XXVIII-lea an al apariției (redactor-șef: Alexandru Bantoș), iar una dintre antologiile de profil, cuprinzând, în principal, interviuri cu basarabeni de diferite formații profesionale, științifice și culturale este intitulată Retrospectivă necesară, realizată de Alexandru Bantoș (prezentarea volumului: Dumistrăcel 2007). Pe de altă parte, cunoașterea personală se întemeiază, mai întâi, pe studiul documentelor de limbă realizate de specialiști în cercetarea dialectologică de la Institutul de Lingvistică al Academiei de Științe a Republicii Moldova, iar, în al doilea rând, pe cercetări proprii, desfășurate, între anii 1992 - 1996, conducând o echipă de lucru de la Institutul de Filologie Română "Alexandru Philippide" al Filialei Iași a Academiei Române și având colaborarea unor colegi de la Institutul de Lingvistică al Academiei de Științe a Republicii Moldova.

14. Pe fondul interesului științific de a cunoaște situația limbii române vorbite în Moldova de la est de Prut, chiar în pofida discursului oareacum „crizist", de după 1989, al intelectualilor basarabeni clamând „distrugerea”, "rusificarea completă”, în ansamblu, a limbii lor, am întreprins, pornind de la dialectologie, o cercetare complexă a vorbirii localnicilor din mediul rural.

14.1. Am apreciat că posibilitatea cunoașterii obiective ne-o oferă analiza, diferențiată, a limbajelor „funcționale” cu referire, în esență, la variația «diastratică» şi «diafazică» (Coșeriu) a diferitelor categorii de locutori, ca și a registrelor vorbirii acestora. Într-un studiu având ca temă "graiul pâinii" în lumina „lingvisticii integrale" coșeriene, am analizat, pe baza înregistrărilor efectuate între 1960 și 1964, publicate, între anii 19691981, în patru volume de "texte dialectale” (ca supliment la ALM), expuneri ale unor vorbitori ai graiurilor moldovenești, $\mathrm{cu}$ domiciliul, în perioada anchetelor, începând cu teritoriul Moldovei și al Ucrainei, până în Primorie. Am analizat discursuri reprezentând raspunsuri la întrebări ale anchetatorilor (dialectologi) având ca obiect temele "Cum se coace/face pâinea?”, ,Cum se lucra/-ează pământul/grâul?", „Lucrul la vie”. Pentru a trage concluzii asupra nivelului competenței idiomatice a vorbitorilor graiurilor „moldovenești”, am ținut seama de teza coșeriană privitoare la 
relația dintre competența lingvistică şi cunoaşterea lucrurilor: limbajele tehnice, adică "tot ce într-o tradiție lingvistică este "nomenclatură»", corespund "tradiției care se referă la cunoaşterea lucrurilor înseşi", ceea ce se aplică şi „lexicului ştiinței şi tehnicii populare” (Coșeriu 2000: 253).

14.2. Pentru descrierea unor elemente de bază ale civilizației materiale a țăranilor din Basarabia şi a celor "colonizați” spre Pacific, analiza noastră constată, în textele anilor '70, păstrarea cuvintelor din fondul de bază al dacoromânei numind făcutul şi coacerea pâinii, cultivarea tradițională a pământului, creşterea oilor şi lucrul la vie. De exemplu, în ceea ce privește lexicul prin care se descrie coacerea pâinii, pe fondul întrebuințării curente a verbelor, substantivelor, adjectivelor şi a uneltelor gramaticale din lexicul de bază al dacoromânei (cu apariția unui singur cuvânt rusesc, un termen general, mucenie 'munca, facerea'), termenii esențiali referitori la produsele finite, la materii, acțiuni, instalații şi unelte sunt [a] de origine latină sau creații pe teren românesc; urmează [b] împrumuturile vechi slave sau neoslave comune dacoromânei, apoi [c] împrumuturi turceşti şi greceşti, unele de asemenea cu circulație semnificativă cel puțin pe teritoriul Vechiului Regat, şi, în sfârşit, [d] împrumuturi din limbile rusă sau ucraineană cunoscute şi în graiurile dintre Prut şi Carpați (în special în nordul Moldovei), respectiv în Maramureş. Specificul zonal îl dau [e] termenii pentru produse finite reflectând mai ales adoptarea unor „rețete” de mâncăruri de la ruşi sau ucraineni (Dumistrăcel 2003: 122).

14.3. O situație în mare parte asemănătoare a lexicului de bază putem constata şi cu privire la descrierea generală a lucrării „pe vechi” a pământului, termenii rusești fiind prezenți, în texte, pentru agricultura „pe nou": sisteme tehnice, instalații, agenți, relații economice (ibidem, p. 123124). Face o notă cu totul deosebită prezentarea unei ocupații de tipul „structurilor aproape ireversibile” (Braudel 1984: 115), specific românească pentru zona danubiană a continentului, viticultura, în care nu apare nici un termen de origine rusă şi doar un adjectiv neologic: altoit, referitor la o practică în îngrijirea viței de vie nobile (Dumistrăcel 2003: 124, 130).

Excurs 16. Vezi observații ale lui Fernand Braudel: „Vinul implică întreaga Europă, atunci când e vorba să fie băut şi numai o anumită Europă, atunci când e vorba să fie făcut" (Braudel 1984: 268-269); autorul vorbeşte chiar de „setea violentă dar inexpertă a ruşilor" (p. 271).

Aşadar, atunci când se refereau la ocupațiile tradiționale, reflectând cunoaşterea "lucrurilor", „cunoaşterea non-lingvistică”, vorbitorii limbii române de la est de Prut aduceau mărturia că nu se îndepărtaseră de ceea 
ce Eugeniu Coşeriu numeşte „configurația şi funcționarea limbajului” ca expresie a unei anumite tradiții lingvistice (Coșeriu 1994d: 134).

15. Dat fiind cadrul anterior invocat, examinarea coerenței momentului istoric 1918, a centenarului Unirii și a perspectivelor, din punct de vedere lingvistic, implică şi o comparație ad-hoc, apelând la perspectiva unui anumit demers istoric, cel al "SScolii Analelor", consolidat de Fernand Braudel, istoric pentru care civilizația materială, elemente ale structurilor cotidiene cum sunt, de exemplu, felul în care oamenii se adăpostesc, se îmbracă şi se hrănesc, în speță pâinea sau vinul fiind personajele principale. Or, punctul de vedere al "lingvisticii integrale", coşeriene, poate fi şi se impune conjugat cu perspectivele „istoriei totale” ca ştiință „despre oameni" a "Şcolii Analelor". O primă verificare ne-o oferă faptul că, de exemplu, relația dintre muncă şi limbaj, cele două dimensiuni fundamentale ale omului descoperite de Hegel, a fost descrisă de Eugeniu Coşeriu prin trei elemente, construirea şi utilizarea unei locuințe, confectionarea de îmbrăcăminte şi prepararea hranei (Coșeriu 1996: 100), adică prin chiar elementele de bază ce reflectă "structurile cotidianului" ca forme de manifestare a "duratei lungi", a timpului geografic, determinând organizarea raporturilor dintre om şi mediu, ce constituie obiectul de studiu al lui Fernand Braudel din primul volum al lucrării Civilisation matérielle, économie et capitalisme (tradusă la noi sub titlul Structurile cotidianului; cf. Braudel 1984).

15.1. În cercetările dialectologice, zona respectivă face obiectul înregistrărilor obișnuite de "texte", în corelație cu temele chestionarului folosit în anchetă; acestea sunt textele "tematice", „etnotextele". Pe de altă parte, relațiile, firești, dintre anchetator și subiecți conduc, în discuții, la abordarea unor aspecte legate de viața personală a acestora, a membrilor familiei sau a consătenilor, de evenimente sociale sau politice, a schimbărilor din aceste domenii, zonă care, în ceea ce privește vorbirea, se caracterizează, de regulă, prin inovația lingvistică, prezentă, de regulă, în așa-numitele sociotexte.

15.2. Acestor două domenii le-am consacrat o cercetare directă, comparată, în cadrul proiectului „Graiuri românești la est de Carpați: etnoși sociotexte”, a cărui prezentare am întreprins-o într-o Anexă la studiul menționat în nota de la începutul acestui articol . Ca rezultate, în rezumat, aveam să constatăm existența unui fond popular lexical comun graiurilor moldovenești din dreapta și din stânga Prutului, prezent în etnotexte, iar, pe de altă parte, aspectul inovator și diferențiator, prezent în special în sociotexte și în fragmente de acest profil din textele "libere" (narațiuni 
despre evenimente și întâmplări din viața subiecților înregistrați), ilustrate prin neologisme, iar în graiurile din Republica Moldova și prin împrumuturi din limba rusă sau ucraineană, ca și prin calcuri semantice și sintactice după limba rusă.

16. Perspectiva de ansamblu și elementele continuităţii

16.1. Încheind această expunere privitoare la o evidentă importanță, pentru caracterizarea, prin cercetări dialectologice, a trăsăturilor esențiale, din perspectivă geolingvistică, ale dacoromânei, subliniem faptul că am avut în vedere, în primul rând, concluziile la care ne conduce metoda geografiei lingvistice, concretizată în realizarea de hărți lingvistice, cu interes special pentru statutul lingvistic al idiomului populației de limbă romanică trăitoare, în general, pe teritoriul actualei Republici Moldova. În al doilea rând, din aceeași perspectivă, pentru cunoașterea limbii în acțiune, a limbajului, am prezentat rezultate ale analizei unor discursuri ale vorbitorilor graiurilor populare din aceleași spații, pentru anii '80 ai secolului trecut. În ceea ce privește concluziile, nuanțate, referitoare la unitatea lingvistică a vorbirii populare românești de pe teritoriul României și al Republicii Moldova, aducem, în sfârșit, mărturia sondajelor proprii din înregistrările din baza de date constituită prin anchetele de teren efectuate între anii 1992 și 1996, în cadrul proiectului „Graiuri românești la est de Carpați: etno- și sociotexte", al cărui profil a avut în vedere, de la început, zona asemănărilor și a deosebirilor.

16.2. Departe de a neglija deosebiri existente la nivelul lexicului graiurilor dacoromânei, cercetarea specificului acestei limbi romanice evidențiază unitatea ei în ceea ce privește fondul principal lexical, iar, apoi, configurări macro-zonale (un areal nordic și altul sudic) explicabile istoric, atât în ceea ce privește complementaritatea lexicului moștenit din latină, cât și în ceea ce privește complementaritatea cu elemente din fondul autohton, respectiv ale acestor componente în raport cu cele mai vechi împrumuturi, reprezentând adstratul slav, respectiv, într-o situație specială, cu împrumuturile din maghiară din arealul nordic. Evident, nu ne referim aici la situația, în evoluție, a limbii literare. Din perspectivă micro-zonală, lexicul graiurilor din diferite spații ale dacoromânei se resimte de contactele directe ale românilor cu vorbitori ai limbilor, variate și ca familii, care înconjură insula romanică a dacoromânei, dar fără ca influențele rezultate să ducă la constituirea unei alte limbi romanice, în vreo arie laterală (cum ar fi, în cauză, în spațiul răsăritean al Moldovei).

16.3. În cursul istoriei, lexicul împrumuturilor se dovedește adesea perisabil, ca unul al acumulărilor „de consum”, unitatea asigurând-o 
depunerea în banca memoriei limbii. După Eugeniu Coșeriu, limba română ca „limbă istorică” reflectă o marcată unitate din perspectiva "dialectului dacoromân”, identificat în „limba română”, atât la nivelul limbii populare, ca unitate a graiurilor, cât și la nivelul limbii literare, ca unitate de cultură, aspect ce constituie o componentă a acelei „identități românești plurale”, după fericita expresie a unui lingvist contemporan (Alexandrescu: 2018).

16.4. Revenind la titlu, avem satisfacția să admitem că opera lui Weigand a reprezentat preludiul, iar „Atlasul lingvistic român” a schițat imaginea prospectivă a realității şi a conceptului, cu elementele de analiză ce se vor dovedi fructuoase pe terenul cercetării de viziune dialectologică.

\section{NOTE:}

[1]. Textul de față constituie o variantă, prescurtată, a studiului „Știința varietății lingvistice diatopice în sprijinul unității naționale: de la Weigand la Pușcariu - Pop - Petrovici”, din volumul Lingvistică şi statalitate, Actele colocviului național „Unitate lingvistică - unitate teritorială. Rolul limbii române în Unirea de la 1918" (Iași, 30-31 mai 2018), sub tipar la Editura Academiei Române.

\section{BIBLIOGRAFIE:}

\section{A.Principalele surse}

Atlasul lingvistic român pe regiuni. Basarabia, Nordul Bucovinei, Transnistria, vol. I-IV (1993 - 2002-2003)

Noul Atlas lingvistic al României. Moldova şi Bucovina [volum introductiv], Date despre localități şi informatori, de Vasile Arvinte, Stelian Dumistrăcel, Ion A. Florea, Ion Nuță, Adrian Turculeț, Bucureşti, Editura Academiei, 1987, 420 p.

Noul Atlas lingvistic al României. Moldova şi Bucovina, de aceiaşi autori, vol. I [hărți şi material necartografiat], Bucureşti, Editura Academiei, 1987, XXXIV + 283 p.

Noul Atlas lingvistic român, pe regiuni. Moldova şi Bucovina, de aceiaşi autori, vol. II [hărți şi material necartografiat], Iaşi, Editura Academiei Române, 1997, XXXVI + 306 p.

Noul Atlas lingvistic român, pe regiuni. Moldova şi Bucovina, vol. III. Prospect de aceiaşi autori; colaboratori: Luminița Botoşineanu, Doina Hreapcă, FlorinTeodor Olariu, Veronica Olariu (de la Institutul de Filologie Română „A. Philippide"); Vasile Apopei, Silviu Bejinariu, Cătălin Bulancea (de la Institutul de Informatică Teoretică al Filialei Iaşi a Academiei Române), Iaşi, Editura Universității „Alexandru Ioan Cuza”, 2005, XX + 46 p.; 
Noul Atlas lingvistic român, pe regiuni. Moldova şi Bucovina, vol. III, de Vasile Arvinte, Stelian Dumistrăcel, Ion Florea, Ion Nuță, Adrian Turculeț și Luminița Botoşineanu, Doina Hreapcă, Florin-Teodor Olariu, Iaşi, Editura Universitătii „Alexandru Ioan Cuza", 2007, LXVIII + 388 p.;

Noul Atlas lingvistic român, pe regiuni. Moldova şi Bucovina, vol. IV, de Vasile Arvinte, Stelian Dumistrăcel (și coordonator), Adrian Turculeț și Luminița Botoşineanu, Doina Hreapcă, Florin-Teodor Olariu, Veronica Olariu, Iaşi, Editura Universității „Alexandru Ioan Cuza”, 2014, LXX + 365 p., volum distins cu premiul „Bogdan Petriceicu Hasdeu” al Academiei Române;

Noul Atlas lingvistic român, pe regiuni. Moldova şi Bucovina. Texte dialectale, culese de Stelian Dumistrăcel şi publicate de Doina Hreapcă şi Ion-Horia Bîrleanu, vol. I, partea 1, Iaşi, Editura Academiei Române, 1993, XCI + 347 p.

Noul Atlas lingvistic român, pe regiuni. Moldova şi Bucovina. Texte dialectale, de aceiaşi autori, vol. I, partea a 2-a, Iaşi, Editura Academiei Române, 1995, LXVIII + $350 \mathrm{p}$.

Noul Atlas lingvistic român, pe regiuni. Moldova şi Bucovina. Texte dialectale, culese de Ion-Horia Bîrleanu şi publicate de Doina Hreapcă şi Ion-Horia Bîrleanu, cu o prefață de Stelian Dumistrăcel, vol. II, partea 1, Bucureşti, Editura Academiei Române, 2002, 340 p.

Texte dialectale culese de V. Melnic, V. Stati, R. Udler, volumul I, partea I, supliment la Atlasul lingvistic moldovenesc (ALM), Chişinău, 1969; I/II, de aceiaşi autori, volumul I, partea a II-a, Chişinău, Editura "Ştiința", 1971; II/I: publicate sub conducerea şi sub redacția lui R. Ia. Udler, de A.N. Dumbrăveanu şi E. N. Constantinovici, volumul II, partea I, Chişinău, Editura "Ştiința", 1971; II/II: publicate de A. N. Dumbrăveanu, sub redacția lui V. N. Stati, volumul II, partea a II-a, Chişinău, Editura "Ştiința", 1981.

\section{B. Exegeze}

Alexandrescu 2018 = Sorin Alexandrescu, Pentru o identitate românească plurală: România 1918-2018, comunicare la Simpozionul internațional „1918 - 2018. Limba şi cultura română - structuri fundamentale ale identității naționale: evaluări, perspective", Iași, 26-28 septembrie 2018

Arvinte 1992-1993 A = Vasile Arvinte, Contribuția lui Gustav Weigand la dezvoltarea dialectologiei românești, în „Anuar de lingvistică și istorie literară”, t. XXXIII, p. $29-42$

Arvinte 2003 = Vasile Arvinte, Ernst Gamillscheg (1887-1971) și Günter Reichenkron (1907-1966). Contribuțiile lor la studiul limbii române, în vol. Intâlniri între filologi români şi germani, Cluj-Napoca, 2003, p. 149-155

Arvinte 2006 (1999) = Vasile Arvinte, Conceptia lui A. Philippide cu privire la formarea limbii şi a poporului român, în vol. Studii de istorie a limbii române, Iaşi, Editura Universității „Alexandru Ioan Cuza”, p. 63-69 
Bahnaru 2016 = Vasile Bahnaru, Institutul de Filologie și aniversarea a LXX-a a Academiei de Științe a Moldovei, în „Philologia”, LVIII, nr. 3-4, p. 3-33

Bartoli 1925 = Matteo Bartoli, Introduzione alla neolinguistica (Principi - scopi metodi), Genova, Olschki

Braudel 1984 = Fernand Braudel, Structurile cotidianului: posibilul şi imposibilul, vol. I, traducere şi postfață de Adrian Riza; Bucureşti, Editura „Meridiane”

Cazacu-Todoran 1965 = B. Cazacu, Romulus Todoran, Observații asupra lexicului limbii române. Trăsături specifice și arii lexicale, în "Studii şi cercetări lingvistice", XVI, nr. 2, p. 185-207

Ciureanu 1940-1941 = Petru Ciureanu, recenzie la Gáldi, Problemi di geografia linguistica nel rumeno del Settecento, în „Buletinul Institutului de Filologie Română «Alexandru Philippide»", 7-8, p. 388-392

Coroliuc 2013 = Alina Loredana Coroliuc, Gustav Weigand și geografia lingvistică /macau.uni-kiel.de/

Coserio 1980 = Eugenio Coserio, Vom primat der Geschichte. Oswald Szemerényi zu seinem 65. Geburtstag, în "Sprachwissenschaft”, 5/2, Heidelberg, Karl Winter Universitätsverlag, p. 125-145

Coserio 1982 = Eugenio Coseriu, Balkanismen oder Romanismen? Methodisches zum sog. "Balkansprachbund”, in Fakten und Theorien. Beiträge zur romanischen und allgemeinen Sprachwissenschaft, Festschrift für Helmut Stimm zum 65. Geburtstag, Tübingen, Narr Verlag, p. 37-43.

Coșeriu 1994a = Eugeniu Coşeriu, Limba română în fața Occidentului. De la Genebrardus la Hervás. Contribuții la istoria cunoaşterii limbii române în Europa occidentală, în românește de Andrei A. Avram, Cluj-Napoca, „Dacia”

Coșeriu 1994 $4^{\mathrm{b}}$ = Eugeniu Coșeriu, Despre aşa-zisa "limbă moldovnească", fragment din comunicarea Latinitatea orientală, prezentată la Congresul al V-lea al Filologilor Români, Iași - Chișinău, 6-9 iunie 1994 (text republicat in revista „Limba română” /Chișinău/, XVII, 207, nr. 3, p. 27)

Coșeriu $1994^{c}=$ Eugeniu Coșeriu, Latinitatea orientală , comunicare la Congresul al V-lea al Filologilor Români, Iași - Chișinău, 6-9 iunie 1994

Coșeriu 1994 ${ }^{\mathrm{d}}=$ Eugeniu Coşeriu, Socio- şi etnolingvistica. Bazele şi sarcinile lor, în vol. Lingvistică din perspectivă spațială și antropologică. Trei studii, cu o prefață de Silviu Berejan și un punct de vedere editorial de Stelian Dumistrăcel, Chișinău, „Știința”, p. 129-156

Coșeriu 1996 = Eugeniu Coșeriu, Lingvistica integrală, interviu cu $\sim$ realizat de Nicolae Saramandu, București, Editura Fundației Culturale Române

Coșeriu 2000 = Eugeniu Coșeriu, Limba funcțională, în vol. Lecții de lingvistică generală, traducere din spaniolă de Eugenia Bojoga, cuvânt înainte de Mircea Borcilă, Chișinău, Editura ARC, p. 249-274

Coșeriu 2002 = Eugeniu Coșeriu, Unitate lingvistică - unitate națională, în „Limba română" (Chișinău), XII, 10, p. 125-131

Deroy 1956 = Louis Deroy, L'emprunt linguistique, Paris, Les Belles Lettres 
Dumistrăcel 1978 = Stelian Dumistrăcel, Influența limbii literare asupra graiurilor dacoromâne. Fonetica neologismului, București, Editura Științifică și Enciclopedică

Dumistrăcel 1989a = Stelian Dumistrăcel, Semnificația ariilor regionale ale unor elemente autohtone din vocabularul limbii române, în vol. Dialectologica, Bucureşti, Societatea de Științe Filologice, p. 49-64

Dumistrăcel $1989^{b}$ = Stelian Dumistrăcel, O problemă de etnoarheologie: «argeaua de țesut» in locuinte din secolele I-XI de pe teritoriul României, în "Revista de etnografie și folclor", t. 34, nr. 4, p. 329-359

Dumistrăcel 1991 = Stelian Dumistrăcel, Permanences de la préhistoire: éléments de la civilisation géto-dace d'après des mots du vocabulaire autochtone de la langue roumaine, în vol. Temps et changements dans l'espace roumain (ed. Al. Zub), Editura Academiei Române, p. 47-62

Dumistrăcel $1995^{\mathrm{a}}=$ Stelian Dumistrăcel, Comportement de recherche sur le lexique autochton du daco-roumain: vers une perspective d'anthropologie culturelle, în "Thraco-Dacica", XVI, 1-2, p. 317-330

Dumistrăcel $1995^{\mathrm{b}}=$ Stelian Dumistrăcel, Sate dispărute - sate amenințate. „Am lucrat o viață și plec într-o dimineață", Iași, Institutul European

Dumistrăcel et alii 1997 = Stelian Dumistrăcel, în colaborare cu Doina Hreapcă şi Ion-Horia Bîrleanu, Ancheta dialectală ca formă de comunicare, Iași, Editura Academiei Române

Dumistrăcel 2003 = Stelian Dumistrăcel, "Graiul pâinii» în lumina «lingvisticii integrale» coșeriene, în „Limba română” (Chișinău), XIII, 4-5, p. 118-131 (sub titlul Limba ca mărturie. Repere pentru o proiecție lingvistică a conceptului «la longue durée», textul a fost publicat şi în vol. Unitatea limbii române, cu privire specială la Basarabia şi Bucovina. Lucrările Sesiunii ştiințifice organizate de Secția de Filologie şi Literatură a Academiei Române, 27 martie 2003, Bucureşti, Editura Academiei Române, 2004, p. 49-77)

Dumistrăcel 2007 = Stelian Dumistrăcel, Credința în izbânda limbii române, prefață la Alexandru Bantoș, Retrospectivă necesară, Chișinău, Casa Limbii Române, p. 7-21

Dumistrăcel 2008 = Stelian Dumistrăcel, Reflexe lingvistice ale Marii Uniri, în vol. Românii din afara granițelor Țării. 90 de ani de la întregirea Regatului României, Iaşi, Casa Editorială Demiurg, p. 116-123

Dumistrăcel-Hreapcă 2009a = Stelian Dumistrăcel, Doina Hreapcă, Histoire des dialectes dans la Romania: la Romania du Sud-Est, în vol. Romanische Sprachgeschichte / Histoire linguistique de la Romania. Ein internationales Handbuch zur Geschichte der romanischen Sprachen, editat de Gerhard Ernst, Martin-Dietrich Glessgen, Christian Schmitt, Wolfgang Schweickard, vol. 3, Berlin - New York, Walter de Gruyter, p. 2459-2478

Dumistrăcel $2009^{\mathrm{b}}=$ Stelian Dumistrăcel, Alexandru Philippide - Gustav Weigand: ipostaze, în „Philologica Jassiensia”, V, nr. 1 /9/, p. 7-42

Dumistrăcel et alii $2011=$ Stelian Dumistrăcel, Doina Hreapcă, Luminița Botoșineanu, De la atlasul lingvistic național la atlasele regionale: semnificația 
diferențelor, în Studii de dialectologie, istoria limbii şi onomastică. Omagiu Domnului Teofil Teaha, Bucureşti, p. 219-242

Dumistrăcel-Hreapcă 2018 = Stelian Dumistrăcel, Doina Hreapcă, Eugeniu Coseriu: une perspective romane dans l'étude de la phraséologie roumaine, comunicare la IV Congresso Internazionale di fraseologia e paremiologia: „Fraseologia e paremiologia, roba da matti!", Bucureşti, 27-29 septembrie 2017, sub tipar

Gáldi 1938 = Ladislao Gáldi, Problemi di geografia linguistica nel rumeno del Settecento, publicație din seria "Annuario dell'Accademia d'Ungheria", vol. XVI, Roma

Gamillscheg 1940a = Ernst Gamillscheg, Der rumänische Sprachatlas und seine Bedeutung für die Slavistik, în "Zeitschrift für Slavische Philologie”, Bd. XVII, Heft 1, p. 143-168

Gamillscheg $1940^{\mathrm{b}}=$ Ernst Gamillscheg, Die Bedeutung des rumänischen Sprachatlas für die ungarische und türkische Philologie, în „Ungarische Jahrbüucher", XX, p. 7-34

Heitmann 1956 = Klaus Keitmann, Rumänische Sprache und Literatur in Bessarabien und Transnistrien (die sogenannte moldauische Sprache und Literatur), în "Zeitschrift für romanische Philologie", LXXXI, p. 102-156

Jaberg 1937 = Karl Jaberg, Tagebuchbläter, în vol. Sprachwissenschaftliche Forschungen und Erlebnisse, Paris-Zurich-Leipzig, p. 10-24

Jaberg 1940 = Karl Jaberg, Der Rumänische Sprachatlas und die Struktur des Dakorumänischen Sprachgebiets, în „Vox romanica”, V, p. 49-87

Lombard 1956/1959 = Alf Lombard, La lingua letteraria meno fissata: il rumeno, comunicare la Congresso Internazionale di Studi Romanzi (Firenze, 3-5 Aprile 1956), vol. 2. Comunicazioni, Parte seconda e terza, Firenze, Sansoni, 1959, p. 283-286

https://ro.wikipedia.org/wiki/Eugen_Co\%C8\%99eriu - cite note-4 MeyerLübke 1911 = Wilhelm Meyer-Lübke, Romanisches etymologisches Wörterbuch Heidelberg, Winter

Pavel 1993 = Vasile Pavel, Preliminarii [cuvânt introductiv], la Atlasul lingvistic român pe regiuni. Basarabia, nordul Bucovinei, Transnistria, vol. 1, Chișinău, «Știința», p. 6-9

Petrovici $1940=$ Atlasul linguistic român, publicat de Muzeul Limbii Române din Cluj, sub conducerea lui Sextil Pușcariu. Partea II (ALR II), vol. I: A. Corpul omenesc, boale (și termeni înrudiți); B. Familia, nașterea, copilăria, nunta, moartea, viața religioasă, sărbători; C. Casa, acareturile, curtea, focul, mobilierul, vase, scule, de Emil Petrovici, Leipzig, Otto Harrassowitz

Petrovici 1970 (1954) = Emil Petrovici, Repartiția graiurilor dacoromâne pe baza "Atlasului lingvistic român", în vol. Emil Petrovici, Studii de dialectologie și toponimie, volum îngrijit de I. Pătruț, B. Kelemen, I. Mării, București, Editura Academiei, p. 38-49

Petrovici 1988 = Emil Petrovici, Atlasul lingvistic român II. Introducere; redactori: Doina Grecu, I. Mării, Rodica Orza; coordonator: I. Mării, Cluj-Napoca 
Pop 1934 = Sever Pop, Cum dispar termenii vechi administrativi şi cum se incetățenesc cei noi, în „Dacoromania”, VII, 1931-1933, p. 61-71

Pop 1938 = Atlasul linguistic român, publicat sub înaltul patronaj al M.S. Regelui Carol II, de Muzeul Limbii Române din Cluj, sub conducerea lui Sextil Pușcariu, profesor la Universitatea din Cluj, membru al Academiei Române, Partea I (ALR I), vol. I: Părțile corpului omenesc şi boalele lui, de Sever Pop, conferențiar la Universitatea din Cluj, Cluj, Muzeul Limbii Române

Pușcariu 1936 = Sextil Pușcariu, Prospect. Atlasul linguistic român (ALR), publicat de Muzeul Limbii Române din Cluj, subt înaltul patronaj al M.S. Regelui Carol II, de Sever Pop, conferențiar la Universitatea din Cluj și Emil Petrovici, profesor la Universitatea din Cluj, subt direcția lui Sextil Pușcariu, profesor la Universitatea din Cluj, directorul Muzeului Limbii Române, București, Monitorul Oficial și Imprimeriile Statului, Iprimeria Națională

Pușcariu 1938 = Sextil Pușcariu, [Prefață la ] Pop 1938, p. 7-14

Pușcariu 1940 = Sextil Pușcariu, Limba română, vol. I. Privire generală, București, Fundația pentru Literatură și Artă Regele Carol II

Sala-Ionescu-Ruxăndoiu 2018 = acad. Marius Sala, Liliana Ionescu-Ruxăndoiu (coord.), Istoria limbii române, vol. I, București, Univers Enciclopedic Gold

Spînu 2009 = Stela Spînu, Graiurile moldovenești din nord-estul Republicii Moldova în cadrul dialectului dacoromân, în „Revistă de lingvistică și știință literară”, nr. 3-4, p. 116-120

Tagliavini 1949 = Carlo Tagliavini, Le origini delle lingue neolatine, Bologna, Riccardo Pàtron

Tagliavini 1956/1959 = Carlo Tagliavini, Una nuova lingua letteraria romanza? Il Moldavo, comunicare la Congresso Internazionale di Studi Romanzi (Firenze, 35 Aprile 1956), Florența, vol. II, partea I, 1959, p. 445-452

Tagliavini 1977 = Carlo Tagliavini, Originile limbilor neolatine. Introducere în filologia romanică, versiune românească îngrijită și coordonată de Alexandru Niculescu, traducere [după ediția a VI-a a originalului, 1972] Anca Giurescu, Mihaela Cârstea-Romașcanu, București, Editura Științifică și Enciclopedică

Udler 1976 = Rubin Udler, Диалектное иленение толдавского языка, I-II, Chișinău, "Știinţa"

Vasiliu $1968=$ Em. Vasiliu, Fonologia istorică a dialectelor dacoromâne, București, Editura Academiei Române

Walde-Pokorny 1973 (1930) = Alois Walde, Vergleichendes Wörterbuch der indogermnischen Sprachen, herausgegeben und bearbeitet von Julius Pokorny, t. I, Berlin-Leipzig, W. de Gruyter

Weigand 1904 = Gustav Weigand, Die Dialekte der Bukovina und Bessarabiens, Leipzig, J.A. Barth 


\title{
The Daco-Romanian Area East of the Carpathians: Milestones from the Memory of Language
}

\begin{abstract}
Having an important ethnographic component, which recorded, through field surveys, the situation of Romanian idioms from 1929 to 1938, the Romanian Linguistic Atlas (the series by Sever Pop and Emil Petrovici) reflects the overall lexical structure of the Romanian language. The latter's territorial unity is proven by the status of most of the elements inherited from Latin, corroborated with substratum elements; both strata are related to the first borrowings from Daco-Romanian, the ones representing the Slavic adstratum. Often, the territorial distribution of these basic elements of historical Daco-Romanian takes the form of two-member complementary areas, a southern and a northern one. In relation to this linguistic complex, regional borrowings owed to the Romanians' contact with the languages of their neighbours (Hungarian, Serbian, Bulgarian, Ukrainian, or Russian) constitute a stock that is variable both from a historical and a functional viewpoint. 100 years after the birth of "Great Romania" this analysis rejects the claim that there existed a "Moldavian" language, different from Daco-Romanian, both in what regards folk speech and its alleged cultivated, literary version. The territorial foundations of the political structure called "Romania", born after the Treaty of Versailles, may also be verified on a map called Völkerkarte des rumanischen Sprachgebietes (i.e. "the ethnic map of the Romanian linguistic territory"), included in Linguistischer Atlas des dacorumänischen Sprachgebietes, published in 1909 by the German linguist Gustav Weigand.
\end{abstract}

Key words: language, Daco-Rmanian Area, idioms, linguistic borrowings. 